\title{
CLIMATIC INFLUENCES ON APPEARANCE AND DEVELOPMENT OF NEOLITHIC CULTURES IN SOUTHERN OUTSKIRTS OF CARPATHIAN BASIN
}

\author{
Katarina Botić \\ Institute of Archaeology,Ljudevita Gaja 32,HR-10000 Zagreb,Croatia,e-mail:kbotic@iarh.hr

\begin{abstract}
Southern outskirts of Carpathian basin, namely the region between Sava, Drava and Danube rivers, have specific climate conditions today partially influenced by geological structure and geographical position. In this region Neolithic Starčevo and Sopot cultures are observed. Radiocarbon dates for Neolithic cultures are used to build a time frame which is compared with climate proxies, especially with Holocene rapid climate events (8.2, 5.9 and $4.2 \mathrm{ka})$, to draw a conclusion on when and how these cultures developed in southern regions of Carpathian basin. Lacking firm geoarchaeological data the results are not conclusive but can provide some insight on how the climate may have directly and indirectly influenced development of Neolithic and beginning of Eneolithic period in the region.
\end{abstract}

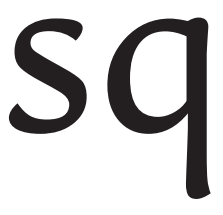

Key words: northern Croatia, Slavonia, Neolithic, Starčevo and Sopot cultures, rapid climate events (8.2, 5.9 and 4.2 ka).

Manuscript received 17 July 2015, accepted 12 February 2016

\section{INTRODUCTION}

Attempts of absolute dating of Neolithic cultures in southern regions of Carpathian basin, i.e. the Slavonia region of northern Croatia, haven't been very successful so far. The main problem is the inconsistency in collecting and interpreting radiocarbon data, often used to date structures and not the remains of material culture. When dates are published and attempts made to firmly connect them with certain phases of known Neolithic cultures, some problems are not detected or are simply ignored (Obelić et al., 2004; Minichreiter and Krajcar Bronić, 2006; Minichreiter, 2007; Krajcar Bronić and Minichreiter, 2007; Krznarić Škrivanko, 2011; Sraka, 2012).

In this paper we are giving an alternative way of narrowing down the possible absolute dating of Neolithic cultures in this region. Sums of radiocarbon dates for two main Neolithic cultures (Starčevo and Sopot) are used as a time frame which is in turn compared to climate proxies and data available from close by regions that already underwent detailed analysis. Although this method is questionable, there is no other geoarchaeological data available yet for the region under observation here. The conclusions, although methodologically questionable, are still sufficiently interesting and open up a new perspective to the archaeological context.
Southern outskirts of Carpathian basin, the region observed in this paper, in geographical sense covers the region between Sava, Drava and Danube rivers (Fig. 1). In geopolitical sense, it is the north-east part of Croatia, i.e. Slavonia and Syrmia region. Drava and Sava rivers flank it from the north and south while Danube river makes its eastern border. Those rivers represent quickest communication routs but they were also source of great annual flooding of the plain ${ }^{1}$, put under control only at the end of the $19^{\text {th }} \mathrm{c}$. by melioration. The floods influenced the Neolithic way of life, especially the choice of settlement positions. By observing these positions, it is possible to come to the conclusion how the flooding and underground water levels changed over time. The water levels depend heavily on the amount of precipitation in the wider region even today, making this region very sensitive to it.

Slavonia region has a specific geological structure (Fig. 2) which enabled permanent settlement of populations from the beginning of Neolithic onwards. Drava and Sava rivers make alluvial plains, both running from the pre Alpine region towards the east. Sava runs slower than Drava, making it easier to cross. Drava was running faster until the hydro power plants were built on it in the $20^{\text {th }} \mathrm{c}$. and it was more difficult to cross in prehistoric times. Both rivers enter Danube river which makes a sharp turn to the east after coming from the north through Pannonian plain. Drava has a lower level of the

The wider region is full of rivers, like Vrbas, Bosna, Drina, Kupa etc. that added to the flooding. Melting of snow in the Alps as well as in the Balkan mountains were additional source of flooding. In 2014 the excessive precipitation in central Balkan region provoked heavy flooding and mudslides in middle and lower flows of the rivers including lower flow of Sava river (Pearson et al., 2014). The damage was horrifying. 


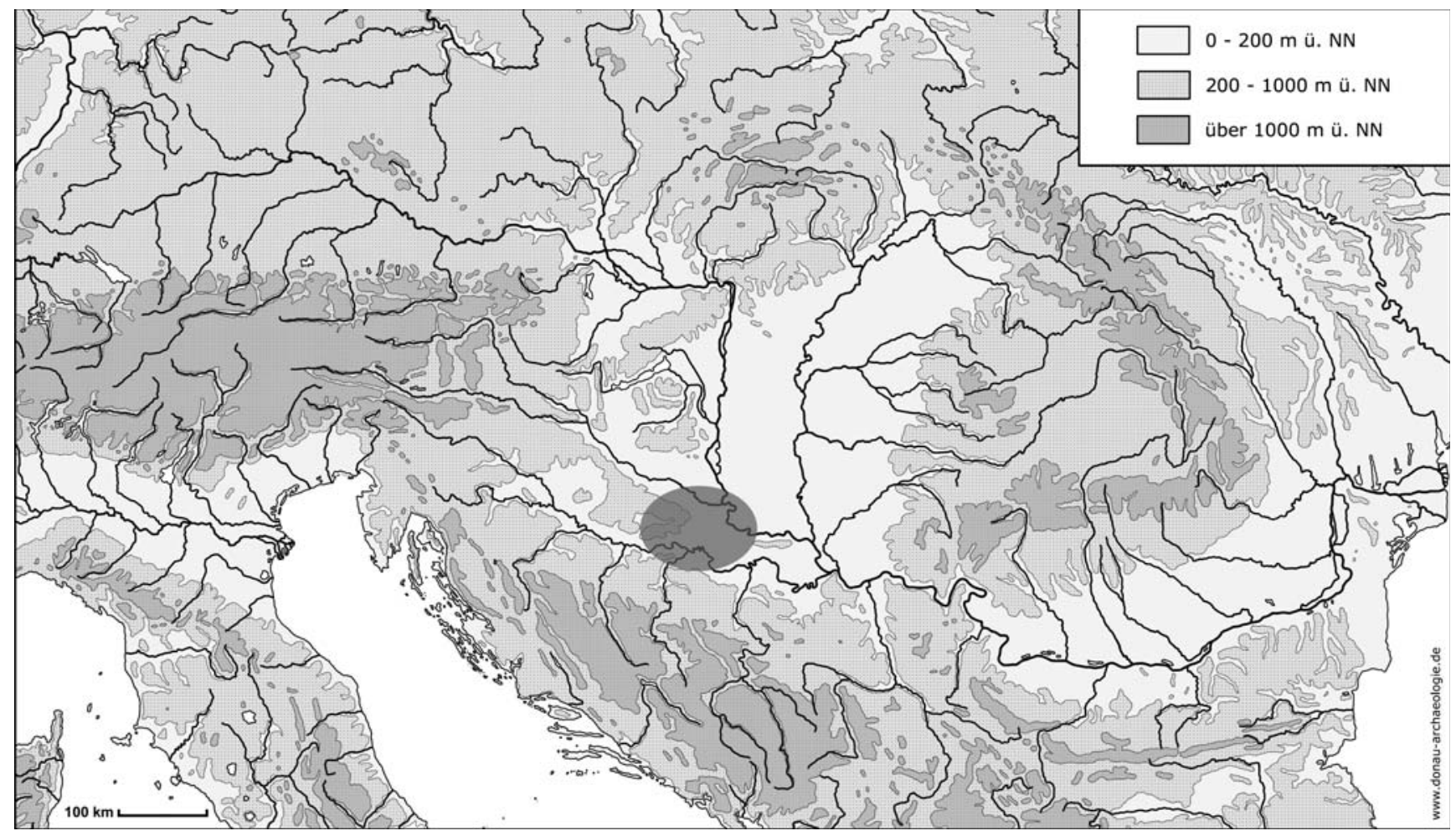

Fig. 1. The position of Slavonia and Syrmia region.

waters and is slowed down by high Danube waters, making a wetland near its mouth called Kopački rit (Burić and Težak Gregl, 2009). Banks of Sava and Drava rivers are low but Danube's right bank is much higher than its left bank - in some parts more than 30 m. Between Sava and Drava Holocene alluvial plains there is a Pleistocene loess ridge (Haase et al., 2007: Fig. 1, Fig. 9 - here, the area in question is marked as containing loess derivates only but see detailed map in Bačani et al., 1999; Burić and Težak Gregl, 2009) known as Đakovo-Vinkovci plateau (Bačani et al., 1999). Loess and its derivatives cover app. $35.7 \%$ of Croatia's total surface area, in some areas reaching thickness of up to $30 \mathrm{~m}$ (Galović, 2005; Galović et al., 2009; Burić and Težak Gregl, 2009). It makes extremely fertile zone exploited from the beginning of agriculture in the Neolithic. The alluvial plains regularly flooded were exceptionally good for growth of penduculate oak (Quercus rubor), while regions west and south of Slavonia are still covered by sessile oak (Quercus petraea) (Pearson et al., 2014).

Recently, the work on collection of subfossil samples for multimillennial tree-ring chronology started. The samples are taken from Sava, Bosna, Vrbas, Kupa and Krapina rivers as well as some archaeological sites (Pearson et al., 2014). This chronology, when finished, will not only present excellent method of dating but will provide much needed climatological data. Climatological studies of Čufar et al. (2014) indicated potential to cross-match material from Croatia with oak growth in the wider region (Pearson et al., 2014). They identified common climatic controls of oak growth at sites in Austria, Hungary, Slovenia, Croatia and Serbia, from $45.00^{\circ}$ to $48.00^{\circ} \mathrm{N}$ latitude and from $13.14^{\circ}$ to $21.63^{\circ} \mathrm{E}$ longitude (Pearson et al., 2014). Cufar et al. (2008) have also constructed an oak tree-ring chronology spanning the period AD 1456-2003 for Slovenia but Croatian chronology already shows potential for time span of several millennia (Pearson et al., 2014) $)^{2}$.

Continental Croatia has a temperate continental climate today. The climate is modified by the maritime influence of the Mediterranean, which is stronger in the area south of the Sava River than in the north, and which weakens towards the east (Zaninović 2008). Although there is no significant difference in mean annual air temperature between Zagreb in the west and Osijek in the east, gradual decrease in mean annual precipitation can be observed (Zaninović 2008). Area of our interest has on average $300 \mathrm{~mm}$ less mean annual precipitation. Eastern part of Slavonia is showing microclimate conditions today but we don't have available data for the past.

\section{RELATIVE CHRONOLOGY OF NEOLITHIC CULTURES IN NORTHERN CROATIA}

Dating of Neolithic cultures in northern Croatia, even after decades of investigation, is not sufficiently precise. The foundation for relative chronology of Neolithic cultures was given by Stojan Dimitrijević in the 1960's and 1970's. It suffered very little change since and it is still in use today.

The beginning of Neolithic in northern Croatia was marked by appearance and development of Starčevo culture which was divided by S. Dimitrijević into 6 phases with one additional final phase: Monochrom, Linear A, Linear B, 


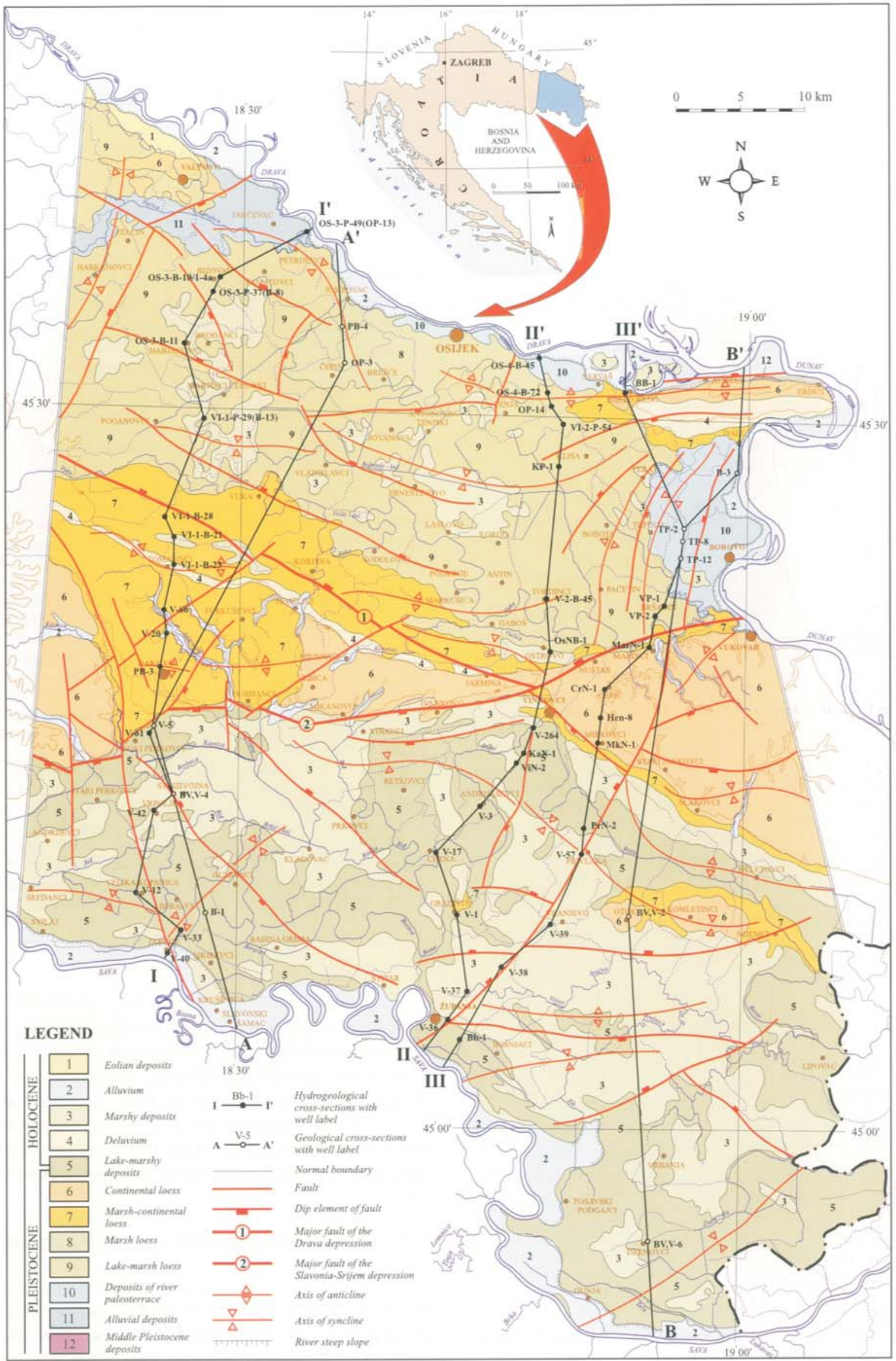

Fig. 2. Geological map (after Bačani et al., 1999: 142, Fig. 1). 


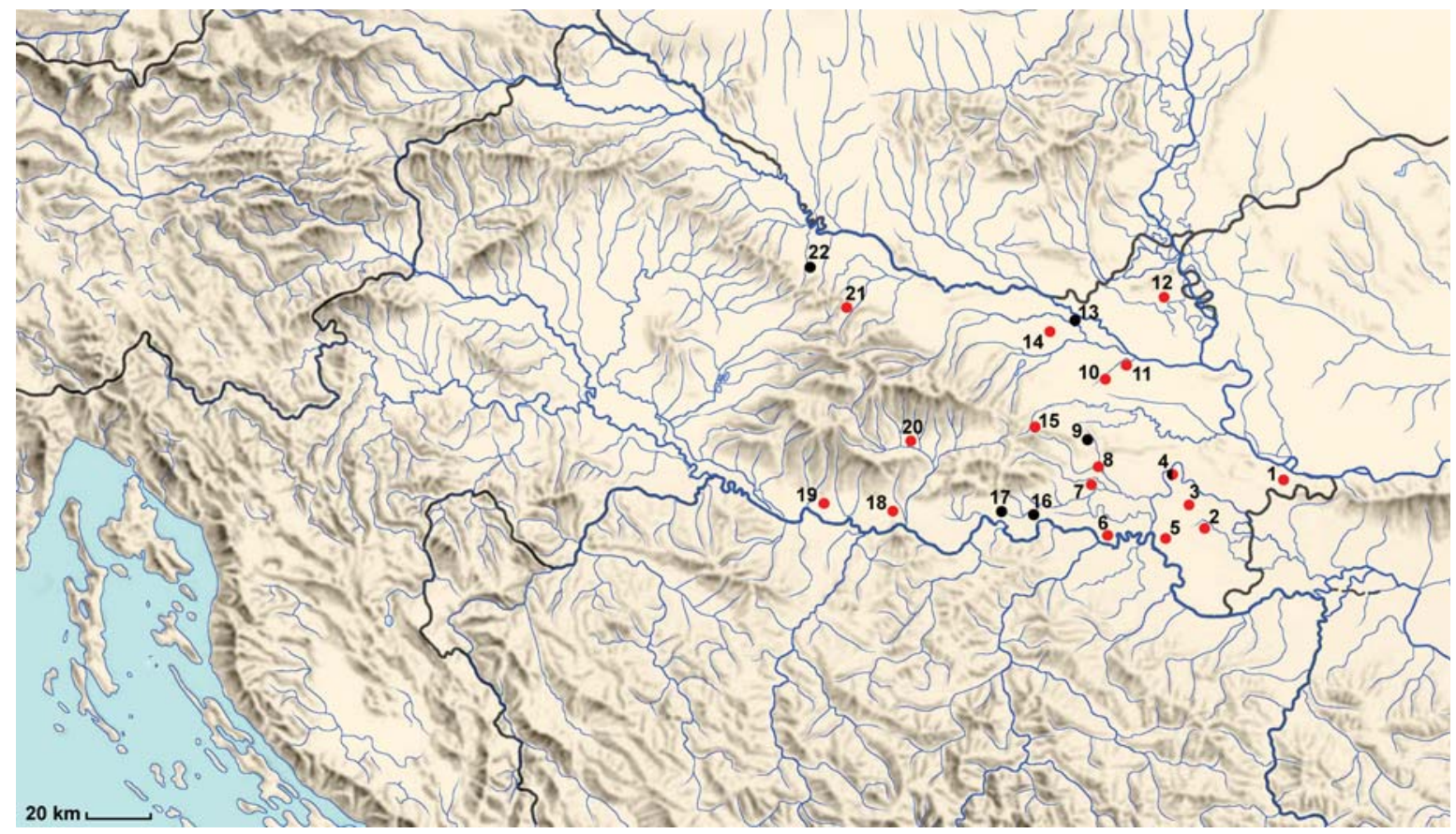

Fig. 3. Neolithic sites radiocarbon dated: 1 - Bapska; 2 - Otok-Mandekov vinograd; 3 - Privlaka-Gradina; 4 - Sopot; 5 - Županja, Dubovo-Košno; 6 - Kruševica-Njivice; 7 - Novi Perkovci-Krčavina; 8 - Ivandvor-šuma Gaj; 9 - Tomašanci-Palača; 10 - Čepin-Ovčara/ Tursko groblje; 11 - Osijek-Hermanov vinograd; 12 - Kneževi vinogradi; 13 - Belišće-Staro Valpovo; 14 - Golinci-Selište; 15 Podgorač-Ražište; 16 - Zadubravlje-Dužine; 17 - Slavonski Brod-Galovo; 18 - Nova Kapela-Ravnjaš; 19 - Nova Gradiška-Slavča; 20 Vidovci-Glogovi; 21 - Pepelana; 22 - Virovitica-Brekinja (Starčevo culture sites black, Sopot culture sites red).

Girlandoid, Spiraloid A, Spiraloid B, Ždralovi final phase (Dimitrijević, 1969, 1979). After extensive work on Pepelana site in 1985, K. Minichreiter filled in this division of Starčevo culture with additional Linear $C$ phase for western Croatia (Minichreiter, 1992) while a little later Z. Marković gave his division of the same culture: Starčevo 1, Starčevo $2 A$, Starčevo $2 B$, Starčevo 3, Starčevo $4 A$, Starčevo $4 B$ (Marković, 1994).

The end of Neolithic was marked by Vinča and Sopot cultures in the observed region. Vinča culture was present only in the easternmost part of the region of Croatia and it gave impulse that lead to the development of Sopot culture. The latter was first linked to the Vinča B phase but recently, after new archaeological research and new radiocarbon dates published, especially in Hungary, it is believed to have appeared at the end of Vinča A phase (Link, 2006; Kalitz et al., 2007) (Fig. 6). Sopot culture later appeared in several regional variants: Ražište type, Pepelana type, Brezovljani type, all in the west of northern Croatian territory, together with classical Sopot culture in the east. Again, the first division of Sopot culture was given by S. Dimitrijević (Phase IA, phase IB, phase II, phase III) (Dimitrijević, 1968, 1971) which was later filled in by Z. Marković (Marković, 1994). He added a short $4^{\text {th }}$ phase already parallel with the first Eneolithic cultures in the region (Marković, 1985, 1994, 2012) which was latter recognized on Sopot site itself (Krznarić Škrivanko, 2007; Balen et al., 2009). Thus, the end of Sopot culture was postponed from the beginning of Vinča D to the end of Vinča D-2/D-3 phase (Marković, 1994).

\section{ABSOLUTE DATING OF NEOLITHIC CULTURES IN NORTHERN CROATIA}

There are several problems linked to the attempt of absolute dating of these two cultures. Firstly, from around 150 known Starčevo culture sites, only 6 have been radiocarbon dated with total of 32 dates (Fig. 3, black) and from several hundred known Sopot sites, only 17 have been radiocarbon dated with total of 71 dates (Fig. 3, red). Furthermore, the dates published are only linked to the structures at best and not to the remains of material culture (i.e. context) thus not providing firm dating of specific phases of both Neolithic cultures. Nevertheless, these radiocarbon dates provide a rough time frame for the beginning and the end of each culture even giving limits to certain phases of these cultures.

The oldest radiocarbon dates for Starčevo culture come from Galovo and Sopot sites (Tab. 1). At Galovo site, two structures were dated to $6835 \pm 110 \mathrm{BP}(5810-5620 \mathrm{BC})$, $6875 \pm 35 \mathrm{BP}(5800-5715 \mathrm{BC})$ and $6850 \pm 60 \mathrm{BP}(5790-5660$ BC) (Minichreiter and Krajcar Bronić, 2006) ${ }^{3}$. Two more structures from the same site, considered the cult structures by the excavator, were dated even earlier: $7060 \pm 150 \mathrm{BP}$ (6070-5770 BC) and 7000 \pm 140 BP (6000-5740 BC) (Minichreiter and Krajcar Bronić, 2006). Sopot site yielded even older dates: layer before sterile ground was dated to $7120 \pm 50$ BP (6060-5900 BC) while the oldest structure, a pit-dwelling, was dated to $7100 \pm 50 \mathrm{BP}(6060-5890 \mathrm{BC})$ (Krznarić Škrivanko, 2011). 
Table 1

Radiocarbon dates for Starčevo culture used in this paper

\begin{tabular}{|c|c|c|c|c|c|c|}
\hline Site & Lab and code & Material and context & $\begin{array}{l}{ }^{14} \mathrm{C} \text { age } \\
\text { (BP) }\end{array}$ & $\begin{array}{c}\delta^{13} \mathrm{C} /{ }^{12} \mathrm{C} \\
(\% 0)\end{array}$ & $\begin{array}{c}\text { Calibration range } \\
(\%)\end{array}$ & Source \\
\hline \multirow{3}{*}{ Sopot } & Beta 251909 & $\begin{array}{l}\text { tooth from SU } 80 \text { (sq. J25); } \\
\text { layer before sterile ground }\end{array}$ & $7120 \pm 50$ & -20.0 & $\begin{array}{c}6060-5900 \mathrm{BC} \\
(68.2 \%)\end{array}$ & \multirow{3}{*}{ Krznarić Škrivanko, 2011, Table 3} \\
\hline & Beta 251911 & $\begin{array}{l}\text { tooth from SU } 143 \text { (sq. J37); } \\
\text { layer before sterile ground }\end{array}$ & $7110 \pm 50$ & -19.7 & $\begin{array}{c}6060-5900 \mathrm{BC} \\
(68.2 \%)\end{array}$ & \\
\hline & Beta 251910 & $\begin{array}{c}\text { tooth from SU } 519 \text { (sq. K35); } \\
\text { pit-dwelling }\end{array}$ & $7100 \pm 50$ & -20.5 & $\begin{array}{c}6060-5890 \mathrm{BC} \\
(68.2 \%)\end{array}$ & \\
\hline \multirow{7}{*}{$\begin{array}{c}\text { Slavonski } \\
\text { Brod-Galovo }\end{array}$} & I.R.B.Z., Z-3586 & $\begin{array}{c}\text { charcoal from the western cult } \\
\text { structure } 89 \text { (sq. F/12-d), SF } \\
312\end{array}$ & $7060 \pm 150$ & / & $\begin{array}{l}6070-5770 \mathrm{BC} \\
\quad(68.2 \%)\end{array}$ & \multirow{3}{*}{$\begin{array}{l}\text { Minichreiter and Krajcar Bronić, } \\
\text { 2006, Fig. 2; Minichreiter, 2007, Fig. } \\
\text { 1; Krajcar Bronić and Minichreiter, } \\
\text { 2007; Krajcar Bronić, 2011, Fig. } 4\end{array}$} \\
\hline & I.R.B.Z., Z-3584 & $\begin{array}{c}\text { charcoal from the western cult } \\
\text { structure } 149 \text { (sq. E/11-a), SF } \\
150-151\end{array}$ & $7000 \pm 140$ & l & $\begin{array}{c}6000-5740 \mathrm{BC} \\
(68.2 \%)\end{array}$ & \\
\hline & I.R.B.Z., Z-3587 & $\begin{array}{c}\text { charcoal from the western cult } \\
\text { structure } 389 \text { (sq. G/12-a), SF } \\
331\end{array}$ & $6865 \pm 65$ & l & $\begin{array}{l}5850-5710 \mathrm{BC} \\
(68.2 \%)\end{array}$ & \\
\hline & I.R.B.Z., Z-2936 & $\begin{array}{l}\text { charcoal from the kiln } 032 \text {, } \\
\text { pit-dwelling } 9 \text { (sq. C/3) with } \\
\text { 3skeletal burials }\end{array}$ & $6835 \pm 110$ & l & $\begin{array}{l}5810-5620 \mathrm{BC} \\
(68.2 \%)\end{array}$ & $\begin{array}{l}\text { Obelić et al., 2002; Minichreiter and } \\
\text { Krajcar Bronić, 2006, Fig. 2; } \\
\text { Minichreiter, 2007, Fig. 1; Krajcar } \\
\text { Bronić and Minichreiter, 2007; } \\
\text { Krajcar Bronić, 2011, Fig. } 4\end{array}$ \\
\hline & I.R.B.Z., Z-3574 & $\begin{array}{c}\text { charcoal from the pit-dwelling } \\
205 \text { (sq. I/13a,c), SF } 484\end{array}$ & $6875 \pm 35$ & l & $\begin{array}{l}5800-5715 \mathrm{BC} \\
(68.2 \%)\end{array}$ & $\begin{array}{l}\text { Minichreiter and Krajcar Bronić, } \\
\text { 2006, Fig. 2; Minichreiter, 2007, Fig. } \\
\text { 1; Krajcar Bronić and Minichreiter, } \\
\text { 2007; Krajcar Bronić, 2011, Fig. } 4\end{array}$ \\
\hline & I.R.B.Z., Z-3583 & $\begin{array}{c}\text { charcoal from the pit-dwelling } \\
37 \text { (sq. b/10-c), SL } 044\end{array}$ & $6300 \pm 80$ & / & $\begin{array}{l}5380-5290 \mathrm{BC} \\
(68.2 \%)\end{array}$ & $\begin{array}{l}\text { Minichreiter and Krajcar Bronić, } \\
\text { 2006, Fig. 4; Minichreiter, 2007, Fig. } \\
\text { 1; Krajcar Bronić and Minichreiter, } \\
\text { 200; Krajcar Bronić, 2011, Fig. } 4\end{array}$ \\
\hline & I.R.B.Z., Z-2935 & $\begin{array}{l}\text { charcoal from a pit } 15 \text { (sq. } \\
\mathrm{D} / 2 \text { ), with } 1 \text { skeletal burial }\end{array}$ & $6185 \pm 130$ & l & $\begin{array}{c}5300-4960 \mathrm{BC} \\
(68.2 \%)\end{array}$ & $\begin{array}{l}\text { Obelić et al., 2002; Minichreiter, 2007, } \\
\text { Fig. 1; Krajcar Bronić and Minichrei- } \\
\text { ter, 2007; Krajcar Bronić, 2011, Fig. } 4\end{array}$ \\
\hline $\begin{array}{l}\text { Zadubravlje- } \\
\text { Dužine }\end{array}$ & I.R.B.Z., Z-2925 & $\begin{array}{l}\text { charcoal from working pit } 12 \\
\text { (sq. A/20-21) }\end{array}$ & $6260 \pm 130$ & / & $\begin{array}{c}5370-5040 \mathrm{BC} \\
(68.2 \%)\end{array}$ & $\begin{array}{l}\text { Minichreiter and Krajcar Bronić, } \\
\text { 2006, Fig. 5; Minichreiter, 2001; } \\
\text { Krajcar Bronić, 2011, Fig. } 5\end{array}$ \\
\hline
\end{tabular}

The youngest radiocarbon dates for Starčevo culture come from Galovo and Zadubravlje sites (Tab. 1). From Galovo site there are two structures dated to $6300 \pm 80 \mathrm{BP}$ (5380-5290 BC) and 6190 \pm 130 (5300-4960 BC) (Minichreiter and Krajcar Bronić, 2006). From Zadubravlje site one structure was dated to $6260 \pm 130 \mathrm{BP}(5370-5040 \mathrm{BC})$ (Minichreiter, 2001; Minichreiter and Krajcar Bronić, 2006). Here, the obvious problems are too low dates for clearly Starčevo culture structures from both sites that overlap with Sopot culture dates from other sites. It is difficult to say if here we can see the prolonged Starčevo culture life at certain sites or it is just a question of badly dated or corrupt samples.

The beginning of Sopot culture can't be considered without Vinča culture in the wider region. Absolute dating of Vinča culture was recently given by D. Borić (2009): the beginning (Vinča A phase) is dated to 5400/5300-5200 BC while the end (Vinča D phase) is dated to $4850-4650 / 4600$ $\mathrm{BC}$. The only problem noted here is very high end date for Vinča D phase because it doesn't correlate well with dates for the end of Vinča culture in wider region ${ }^{4}$.
The beginning of Sopot culture according to radiocarbon dates (Tab. 2) is quite problematic. Some dates are too high (old wood effect?) but the main problem is the lack of sites with earliest phase (IA) of this culture. So, the oldest dates correspond to the end of the first phase (IB) or later. One comes from Dubovo-Košno site (6320 \pm 100 BP; 5390-5140 $\mathrm{BC})$, the other from Sopot site (6340 \pm 100 BP; $5470-5210$ $\mathrm{BC}$ ) but both were published without remains of material culture. The most probable dates come from Golinci - Selište and Kruševica - Njivice sites (Tab. 2), both corresponding to the IB phase: the first is $6160 \pm 45 \mathrm{BP}(5210-5050 \mathrm{BC})$, the second $6115 \pm 60$ BP (5210-4940 BC).

The youngest radiocarbon dates for Sopot culture (Tab. 2) are much lower than Vinča D phase according to Borić (2009) or somewhat later in the wider region, and they partially overlap with dates for Eneolithic Lasinja culture (Balen, 2008). Several come from Sopot site: $5380 \pm 98$ BP (4340-

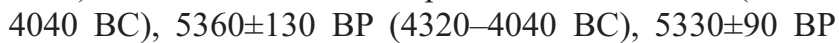
(4250-4040 BC), 5300 $\pm 40 \mathrm{BP}(4250-4030 \mathrm{BC})$ and $5220 \pm$ $100 \mathrm{BP}(4230-3940 \mathrm{BC})$ (Obelić et al., 2002). One date is 
Table 2

Radiocarbon dates for Sopot culture used in this paper

\begin{tabular}{|c|c|c|c|c|c|c|}
\hline Site & Lab and code & Material and context & $\begin{array}{l}{ }^{14} \mathrm{C} \text { age } \\
\text { (BP) }\end{array}$ & $\begin{array}{c}\delta^{13} \mathrm{C} /{ }^{12} \mathrm{C} \\
(\% 0)\end{array}$ & $\begin{array}{c}\text { Calibration range } \\
(\%)\end{array}$ & Source \\
\hline $\begin{array}{c}\text { Županja-Dubovo- } \\
\text { Košno }\end{array}$ & I.R.B.Z., Z-3045 & $\begin{array}{c}\text { Charcoal, SU 1804, square } \\
\text { Z-43d, PU } 339\end{array}$ & $6320 \pm 100$ & / & $\begin{array}{l}5390-5200 \mathrm{BC}(51.2 \%) \\
5170-5140 \mathrm{BC}(5.1 \%)\end{array}$ & $\begin{array}{l}\text { Obelić et al., 2002; Obelić et al., } \\
\text { 2004, Table 1; Marijan, 2001; } \\
\text { Marijan, 2006; Čataj and Janeš, } \\
\text { 2013; Burić, 2015, Tab. } 3\end{array}$ \\
\hline Golinci-Selište & LTL 5772A & Charcoal from SU 113/114 & $6160 \pm 45$ & / & $\begin{array}{l}5210-5050 \mathrm{BC}(68.2 \%) \\
5230-4980 \mathrm{BC}(95.4 \%)\end{array}$ & Čataj and Janeš, 2013 \\
\hline Kruševica-Njivice & I.R.B.Z., Z-3595 & Sq. N24, SU 314, half earth-hut & $6115 \pm 60$ & l & $\begin{array}{l}5210-5160 \mathrm{BC}(15.1 \%) \\
5080-4940 \mathrm{BC}(48.1 \%)\end{array}$ & $\begin{array}{l}\text { Obelić et al., 2011; Krznarić } \\
\text { Škrivanko, 2011; Čataj and Janeš, } \\
2013\end{array}$ \\
\hline \multirow{6}{*}{ Sopot } & I.R.B.Z., Z-2826 & $\begin{array}{c}\text { Charcoal, part of wooden con- } \\
\text { struction supporting wall of } \\
\text { house SU } 11^{*} \text {, probe Sopot III, } \\
\text { block } 5 \text {, quadrant I/6, } 2.11 \mathrm{~m} \\
\text { depth }\end{array}$ & $6340 \pm 100$ & 1 & $5470-5210 \mathrm{BC}(65.7 \%)$ & $\begin{array}{l}\text { Obelić et al., 2002; Burić, 2015, } \\
\text { Tab. } 1\end{array}$ \\
\hline & I.R.B.Z., Z-2827 & $\begin{array}{l}\text { Charcoal from SU } 11 \text { (sq. J } \\
\text { 6/97); house floor }\end{array}$ & $5380 \pm 98$ & / & $\begin{array}{l}4340-4210 \text { BC }(36.8 \%) \\
4200-4140 \text { BC }(13.5 \%) \\
4130-4040 \text { BC }(17.9 \%)\end{array}$ & \multirow{3}{*}{$\begin{array}{l}\text { Obelić et al., 2002; Obelić et al., } \\
\text { 2004, Table 1; Krznarić Škri- } \\
\text { vanko, 2011, Table 3; Čataj and } \\
\text { Janeš, 2013; Burić, 2015, Tab. } 1\end{array}$} \\
\hline & I.R.B.Z., Z-2754 & $\begin{array}{l}\text { Charcoal from SU } 11 \text { (sq. G } \\
\text { 9/97): house floor }\end{array}$ & $5360 \pm 130$ & l & $\begin{array}{l}4320-4270 \text { BC }(14.4 \%) \\
4260-4040 \text { BC }(53.8 \%)\end{array}$ & \\
\hline & I.R.B.Z., Z-2911 & $\begin{array}{c}\text { Charcoal from SU } 20 \text { (sq. } \\
\text { H6/01): house floor }\end{array}$ & $5330 \pm 90$ & / & $4250-4040 \mathrm{BC}(66.1 \%)$ & \\
\hline & Beta 230030 & $\begin{array}{l}\text { Charcoal from SU } 222 \text { (sq. } \\
\text { G/H 35): zap. kanala }\end{array}$ & $5300 \pm 40$ & / & $4250-4030 \mathrm{BC}$ & $\begin{array}{l}\text { Krznarić Škrivanko, 2011, Tab. 3; } \\
\text { Čataj and Janeš, } 2013\end{array}$ \\
\hline & I.R.B.Z., Z-2909 & $\begin{array}{l}\text { Charcoal from SU } 20 \text { (sq. I } \\
\text { 6//99): house floor }\end{array}$ & $5220 \pm 100$ & / & $\begin{array}{l}4230-4180 \text { BC }(8.9 \%) \\
4170-3940 \text { BC }(59.3 \%)\end{array}$ & $\begin{array}{l}\text { Obelić et al., 2002; Obelić et al., } \\
\text { 2004, Table 1; Krznarić Škri- } \\
\text { vanko, 2011, Table 3; Čataj and } \\
\text { Janeš, 2013; Burić, 2015, Tab. } 1\end{array}$ \\
\hline $\begin{array}{c}\text { Nova } \\
\text { Gradiška-Slavča }\end{array}$ & $\begin{array}{c}\text { Beta } \\
278786\end{array}$ & Charcoal from SU 91 & $5290 \pm 40$ & -24.3 & $4250-4030 \mathrm{BC}$ & $\begin{array}{l}\text { Mihaljević, 2013, Table 31; } \\
\text { Burić, 2015, Table } 9\end{array}$ \\
\hline $\begin{array}{c}\text { Osijek-Hermanov } \\
\text { vinograd }\end{array}$ & I.R.B.Z., Z-2830 & $\begin{array}{c}\text { Charcoal from fireplace, depth } \\
1.8-2.0 \mathrm{~m}\end{array}$ & $5260 \pm 120$ & l & $\begin{array}{l}4230-4180 \text { BC }(7.7 \%) \\
4170-3930 \text { BC }(53.2 \%) \\
3860-3810 \text { BC }(7.3 \%)\end{array}$ & $\begin{array}{l}\text { Šimić, 2000; Obelić et al., 2002; } \\
\text { Obelić et al., 2004, Table 1; } \\
\text { Šimić, 2006; Čataj and Janeš, } \\
\text { 2013; Burić, 2015, Tab. } 6\end{array}$ \\
\hline $\begin{array}{l}\text { Otok-Mandekov } \\
\text { vinograd }\end{array}$ & I.R.B.Z., Z-2762 & $\begin{array}{c}\text { Charcoal, square } 10 / \mathrm{ij} \text {, depth } \\
0.77 \mathrm{~m}\end{array}$ & $5330 \pm 120$ & l & $\begin{array}{l}4330-4290 \text { BC (7.1\%) } \\
4260-4040 \text { BC }(57.6 \%)\end{array}$ & $\begin{array}{l}\text { Obelić et al., 2002; Obelić et al., } \\
\text { 2004, Table 1; Čataj and Janeš, } \\
\text { 2013; Burić, 2015, Tab. } 4\end{array}$ \\
\hline
\end{tabular}

* House 11 at Sopot site is dated to the III/IV phase (I.R.B.Z., Z-2754 and I.R.B.Z., Z-2827) but this date is older. It is possible that the sample doesn't belong to this house but to some older construction.

from Nova Gradiška - Slavča site (5300 \pm 40 BP; 4250-3990 BC) (Mihaljević, 2013), one from Osijek - Hermanov vinograd site (5260 $\pm 120 \mathrm{BP} ; 4230-3810 \mathrm{BC})$ and one from Otok - Mandekov vinograd site (5330 \pm 120 BP; 4330-4040 BC) (Obelić et al., 2002). Attempts to firmly date Sopot culture phases weren't successful so far (Obelić et al., 2004, Krznarić Škrivanko, 2011; Sraka, 2012) because too high dates are considered or the $4^{\text {th }}$ phase is ignored, in addition to the fact that the clear context of the finds is missing.

Observing the available radiocarbon dates, even if we ignore their obvious downsides, shows several problems concerning absolute dating of Starčevo and Sopot cultures. The beginning of Starčevo culture fits well the beginning of Neolithic in the wider region (see for example Hertelendi et al., 1995; Biagi and Spataro, 2005; Biagi et al., 2005; Lazarovici, 2006; Minichreiter and Krajcar Bronić, 2006; Budja, 2013 etc.) but dating of its end in the north Croatia is not quite clear. Sopot culture shows problems concerning dating of all the phases, from the beginning until its end. It is worth noting that one date from Hungarian site Sormás-Mátai-dülö (VERA-3102, 6115 \pm 35 BP; 5210-4980 BC) (Barna and Pásztor, 2011), belonging to this site's Sopot level, corresponds well with two dates from Croatian sites GolinciSelište and Kruševica-Njivice (Tab. 2) although the context of these dates is not considered to represent the oldest phase of Sopot culture. As the Sopot culture first appeared in northern Croatia and then spread to the north, the question is when that happened bearing in mind that Vinča culture is older.

All radiocarbon dates available for Starčevo and Sopot cultures, when summed (Fig. 4), give us a time frame which will be used to compare it with climate proxies (Tab. 3). Although this method is not accurate and faces many problems ${ }^{5}$, it is at the moment the only possible way to observe how these cultures fit the Holocene rapid climate events. Unfortunately, no larger archaeological context or geoarchaeological data is available at the moment for the observed region. 


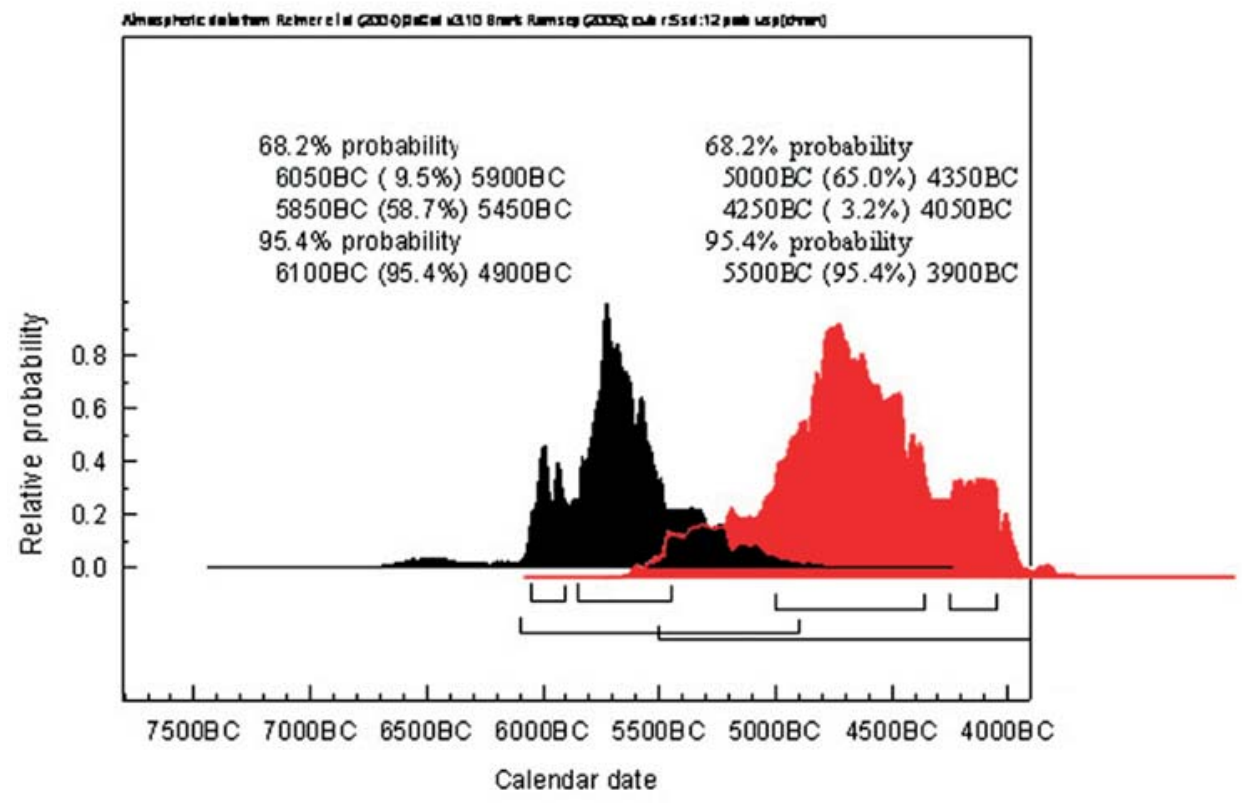

Fig. 4 The sum of radiocarbon dates for Starčevo (black) and Sopot (red) cultures.

This time frame corresponds well with Hungarian Neolithic (Fig. 5) and generally corresponds well with absolute dating of Neolithic in wider region (Fig. 6), although there are some differences - the beginning of Starčevo culture is dated later and the beginning of Eneolithic earlier than in our observed region.

\section{CLIMATE PROXIES}

In recent times the interest for Holocene climate change increased considerably. One of the most remarkable discoveries is the existence of a distinctly repetitive pattern of global cooling anomalies, with major (among other cycles) 1450-year periodicity during the Glacial periods, extending through the Holocene (Weninger et al., 2009). These climate changes were manifested by cooling oscillations, tropical aridity and major atmospheric circulation changes (Budja, 2007) and are known as Rapid Climate Change (RCC) events (Mayewski et al., 2004; Weninger et al., 2009). The existence of rapid fluctuations in Northern Hemispheric Glacial and Holocene atmospheric circulation patterns was first recognised some years ago in a detailed analysis of the GISP2 (Greenland) ice core glaciochemical record (Mayewski et al., 1997; Clare and Weninger, 2010). Subsequent comparisons of the GISP2 record with terrestrial and marine records

Table 3

Absolute chronological time frame for the Neolithic cultures in northern Croatia

\begin{tabular}{|c|l|}
\hline around $6000 \mathrm{BC}$ & the beginning of Starčevo culture \\
\hline $5500-5300 \mathrm{BC}$ & the end of Starčevo culture \\
\hline $5300-5000 \mathrm{BC}$ & the beginning of Sopot culture (?) \\
\hline $5200-5050 \mathrm{BC}$ & $\begin{array}{l}\text { duration of Sopot culture (most of the available } \\
\text { dates) }\end{array}$ \\
\hline $5050-4300 \mathrm{BC}$ & hiatus? (drastic decrease of available dates) \\
\hline $4300-4200 \mathrm{BC}$ & $\begin{array}{l}\text { the end of Sopot culture (the end of Neo- } \\
\text { lithic/beginning of Eneolithic) }\end{array}$ \\
\hline $4200-4000 / 3990 \mathrm{BC}$
\end{tabular}

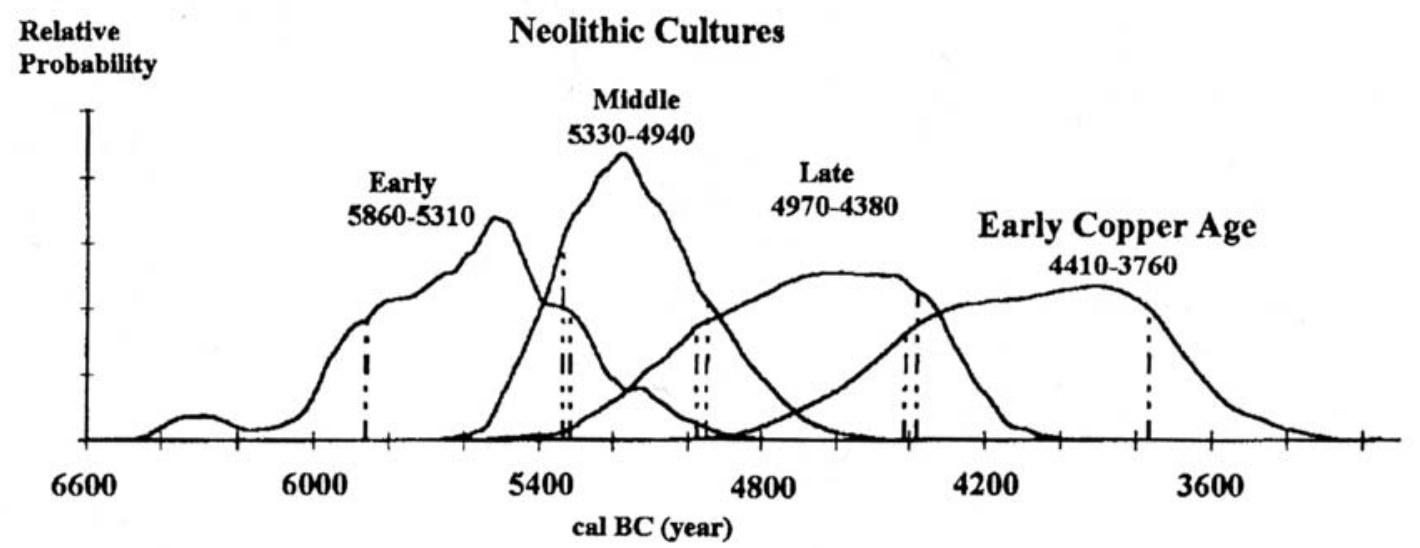

Fig. 5. Diagrammatic representation of the three phases of the Neolithic period (after Hertelendi et al., 1995: 242, Fig. 2). 


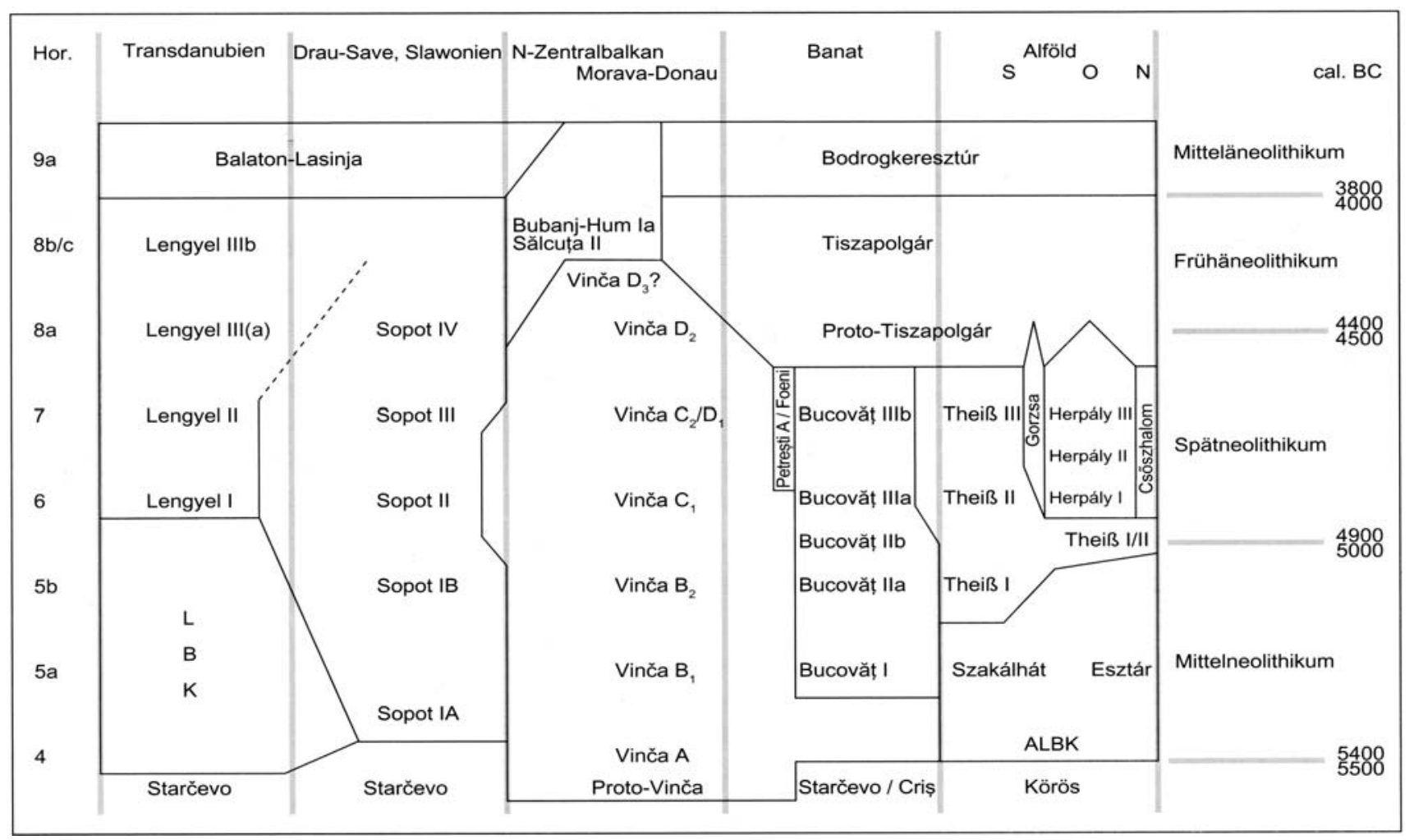

Fig. 6. Chronological table of middle Neolithic and late Neolithic cultural groups in the Carpathian basin (after Link, 2009: 96, Abb. 1).

on a global scale have demonstrated the existence of six distinct time-intervals, each of which showed major cooling anomalies during the Holocene (Mayewski et al., 2004; Clare and Weninger, 2010). The ages attributed to these (wider) Rapid Climate Change (RCC) intervals are: 9000$8000,6000-5000,4200-3800,3500-2500,1200-1000$, and 600-150 calBP (Mayewski et al., 2004; Alley and Ágústsdóttir, 2005; Budja, 2007; Clare and Weninger, 2010; Weninger et al., 2009). The most recent manifestation is known as the Little Ice Age (LIA) (Budja 2007; Clare and Weninger, 2010; Weninger et al., 2009).

For the North Atlantic, these cooling phases are explained with changes in salinity caused by final deglaciation of the Laurentide ice sheet and related fresh-water outbursts into the ocean, as well as iceberg discharges which equally supplied fresh-water to the North Atlantic (Budja, 2007; Gronenborn, 2009), known as Holocene IRD events (Ice Rafted Debris) (Gronenborn, 2009) or Bond events (Bond et al., 1997). IRD events show a good correlation with insolation cycles and solar triggering is considered (Bond et al., 2001; Gronenborn, 2009). These North Atlantic temperature changes and changes in the ocean salinity could also have had hemispherical effect, with teleconnections to the monsoonal cycles (Alley and Ágústsdóttir, 2005; Gronenborn, 2009).

Two of the RCC intervals are important for this paper: 9000-8000 and 6000-5000 calBP (Clare and Weninger, 2010). The bibliography consulted is extensive (Alley et al., 1997; Bond et al., 1997; Bianchi and McCave, 1999; Hu et al., 1999; Perry and Hsu, 2000; Bond et al., 2001; Ogutsov et al., 2001; Sümegi et al., 2002; Magny et al., 2003; Mayewski et al., 2004; Alley and Ágústsdóttir, 2005; Bailey, 2006; Kuper and Kröpelin, 2006; Weninger et al., 2006; BoutRoumazeilles et al., 2007; Budja, 2007; Thomas et al., 2007; Weninger et al., 2007; Clare et al., 2008; Weninger et al., 2008; Berger and Guilaine, 2009; Bocquet-Appel et al., 2009; Gronenborn, 2009; Gronenborn and Sirocko, 2009; Kotova, 2009; Weninger et al., 2009; Clare and Weninger, 2010; Kotova and Makhortykh, 2010; Gulýas and Sümegi, 2011; Lemmen et al., 2011; Carozza et al., 2012; Welc and Marks, 2014 - all with their corresponding bibliography) but we will only take specific RCC intervals into consideration and their correlation with archaeological indicators for the observed region of Slavonia.

\section{2 ka calBP climate event}

The ' $8.2 \mathrm{ka} \mathrm{BP}$ event' is the most unfavourable of all events from the beginning of Holocene including the Little Ice Age (LIA). Anomalies have been observed in paleoclimate archives on a near global scale, except for the high southern latitudes (Budja, 2007). Greenland ice-core records show that temperatures in the North Atlantic region dropped abruptly around $8200 \mathrm{BP}^{6}$ and took around 160 years to recover (Thomas et al., 2007; Weninger et al., 2009). This cooling was caused by flood outburst from the final deglaciation of the Laurentide ice sheet, strengthened atmospheric 


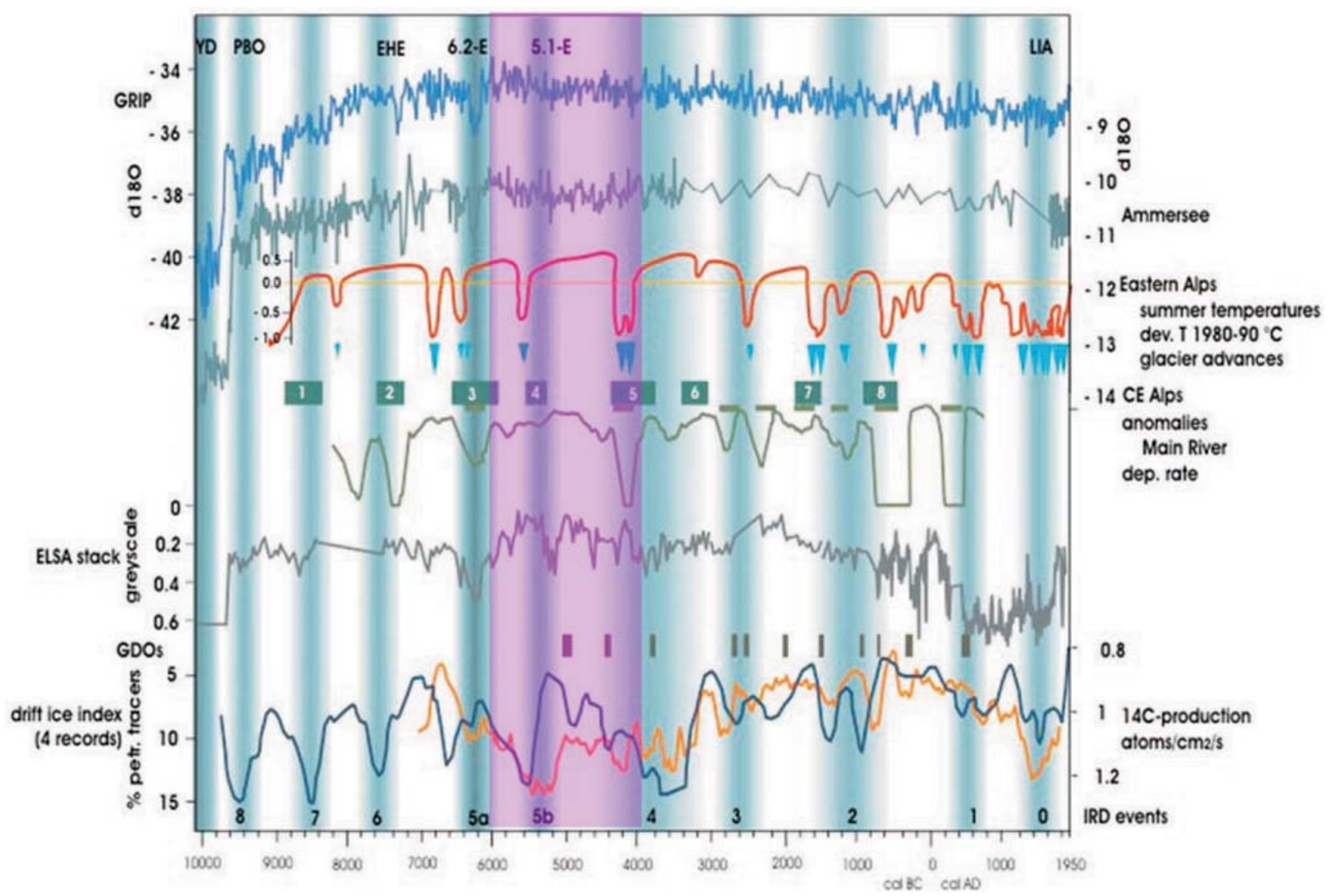

Fig. 7. Selected marine and terrestrial palaeoclimate proxy data for Central Europe. PBO - pre-Boreal oscillation; EHE - early Holocene event; CE - cold events; GDO - germination/dying-off events. Duration of Neolithic in Slavonia region is marked in purple (modified after Gronenborn, 2009: 99, Fig. 2).

circulation over the North Atlantic and Siberia and more frequent polar north-westerly winter outbreaks over the Balkans and Aegean Sea (Budja 2007; Weninger et al., 2009). Extremely cold and dry air flowing rapidly over a warm sea surface caused water evaporation which could have resulted in very abrupt and heavy precipitation (Weninger et al., 2009). Analyzing the marine core LC21, situated near the east coast of Crete in Aegean sea, Weninger et al. (2009) noted three major temperature drops in the south east Aegean, dated to $8.6-8.0 \mathrm{ka}$ calBP, $6.5-5.8 \mathrm{ka}$ calBP and $3.5-2.8$ ka calBP which corresponds to the RCC intervals on a global scale (Figs 7,8).

Decline in winter temperatures of more than $4^{\circ} \mathrm{C}$ was noted in northern Greece (Tenaghi Philippon site) and northwest Romania (Steregoiu and Preluca Tiganului sites) in pollen records. The significant drop of Dead Sea water levels was noted for the period after the $8.6 \mathrm{ka}$ calBP recovering slightly only around $7.5 \mathrm{ka}$ calBP and continuing at relatively low levels until $5.6 \mathrm{ka}$ calBP (Budja, 2007; Weninger et al., 2009). As the Dead Sea level responds primarily to precipitation changes in the northern Jordan Valley, it is possible to conclude that, during the low levels of the Dead Sea, precipitation decreased significantly in the wider eastern Mediterranean region (Weninger et al., 2009) (Figs 9, 10).

In south-central Europe, pollen analysis showed change in terrestrial vegetation in response to the climatic change be- tween 8170 and 7950 calBP. This change is probably direct response to the annual temperatures decreasing by about $2-3^{\circ} \mathrm{C}$ and to increased moisture availability. Southern Balkans faced rainfall seasonality change, with drastic decrease in autumn to spring precipitation and considerable fall of temperatures (Budja, 2007). The reconstruction of climatic parameters from European lake-level fluctuation data suggest that regions at mid-latitudes between $43^{\circ}$ and $50^{\circ} \mathrm{N}$ underwent wetter conditions in response to the cooling, while northern and southern Europe was marked by drier climate (Magny et al., 2003; Budja, 2007).

In the southern Levant, the 8200 calBP 'climate event' was associated with the transition from the Pre-Pottery (PPN) to Pottery Neolithic (PN); the Jericho settlement was abandoned as well as the settlements at Ain Ghazal (Levant), Catalhöyük East (Central Anatolia) and settlements of Cyprus (Budja, 2007; Weninger et al., 2009). It is suggested that this climate event correlated with spread of farming from West Asia and Near East into Europe but there is enough evidence that farming (i.e. pottery) in Europe appeared prior to the 8200 calBP althoug the domestication of animals arrived immediately after (Budja, 2007).

According to Gronenborn (2009), IRD events 5 and 4 were contemporaneous with two major shifts in the Neolithisation process in Temperate Europe (Figs 7, 9). The IRD event $5 \mathrm{a}$ can be linked to the beginning of the Neolithisation 


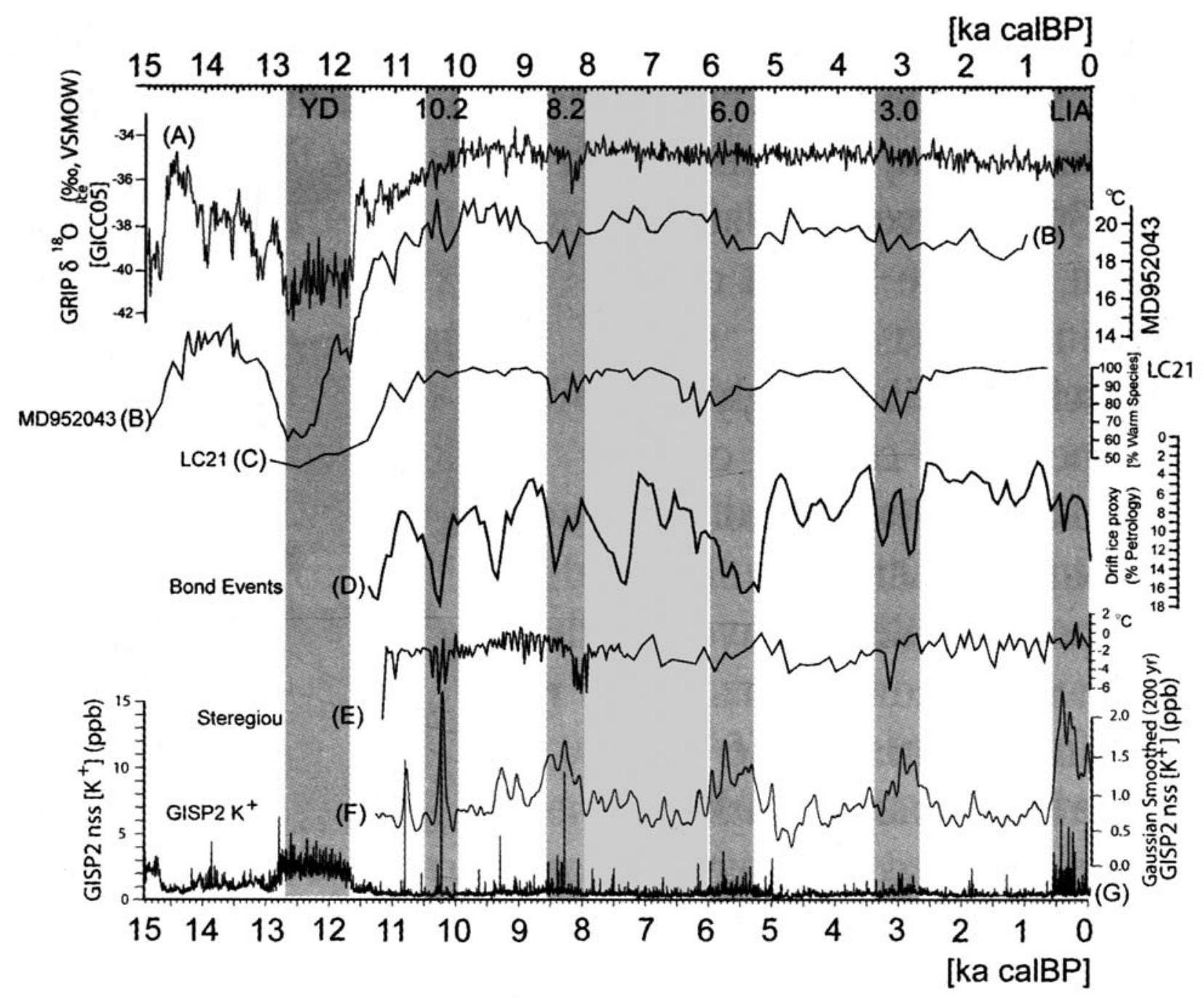

Fig. 8. Northern Hemisphere Palaeoclimate Records showing Holocene Rapid Climate Change (RCC) (site map cf. Fig. 2), (A) Greenland GISP2 ice-core $\delta^{18} \mathrm{O}$ (Grootes et al., 1993), (B) Western Mediterranean (Iberian Margin) core MD95-2043, sea surface temperature (SST) C37 alkenones (Cacho et al., 2001; Fletcher et al., 2008), (C) Eastern Mediterranean core LC21 (SST) fauna (Rohling et al., 2002), (D) North Atlantic Bond-Events, stacked petrologic tracers of drift ice from cores MC52-V29191+MC21-GGC22 (Bond et al., 2001), (E) Romania (Steregoiu), Mean Annual Temperature of the Coldest Month (MTC, ${ }^{\circ} \mathrm{C}$ ) (Feurdean et al., 2008), (F) Gaussian smoothed (200 yr) GISP2 potassium (non-sea salt $\left[\mathrm{K}^{+}\right]$; ppb) ion proxy for the Siberian High (Mayewski et al., 1997; Meeker and Mayewski, 2002), (G) High-Resolution GISP2 potassium (nonsea salt $\left[\mathrm{K}^{+}\right]$; ppb) ion proxy for the Siberian High (Mayewski et al., 1997; Meeker and Mayewski, 2002). Duration of Neolithic in Slavonia region is marked in light gray (modified after Weninger et al., 2009: 9, Fig. 1).

around $6500 \mathrm{BC}$. The IRD event $5 \mathrm{~b}$ started around $5700 \mathrm{BC}$ and ended abruptly around $5100 \mathrm{BC}$ with the 5.1 event, covering more or less the entire extension of the LBK in Central Europe (Gronenborn, 2009).

It can be concluded that the Neolithisation process of south-east and central Europe (regions at mid-latitudes between $43^{\circ}$ and $50^{\circ} \mathrm{N}$ ) was interrupted by 8200 calBP event because of the increase of precipitation, flooding and change in vegetation. The Morava River valley, a waterway connecting the southern Balkans to north-central Europe, was badly affected by river dynamics and floods. It can be speculated that in the Pannonian Plain there was an extension of wetlands and long-term flooding at the time of the climate event, because the records show that it was flooded at least twice a year before the regulation in the $19^{\text {th }}$ century (Bánffy, 2004; Budja, 2007; Bánffy and Sümegi, 2012). This is also true for
Sava, Drava and Danube interfluve (Slavonia region). The initial agriculture in Peloponnesus and most of Balkans predate the climate event (6200-6000 BC) but Neolithic populations crossed Danube and entered the southernmost region of the Pannonian Plain after the major climate fluctuations (i.e. around $6000 \mathrm{BC}$ ) (Budja, 2007).

\section{0 ka calBP climate event}

The time range of the next RCC period ( $6.0 \mathrm{ka}$ calBP) is 6000-5200 calBP. In southern Europe, this period is associated with transition from the final Neolithic (or Late Copper Age/Late Eneolithic, according to region) to the Early Bronze Age. In this part of Europe (Greece, Bulgaria, Romania) archaeological research confirmed an abrupt collapse of longstanding cultural systems and long-lived settlements that can 

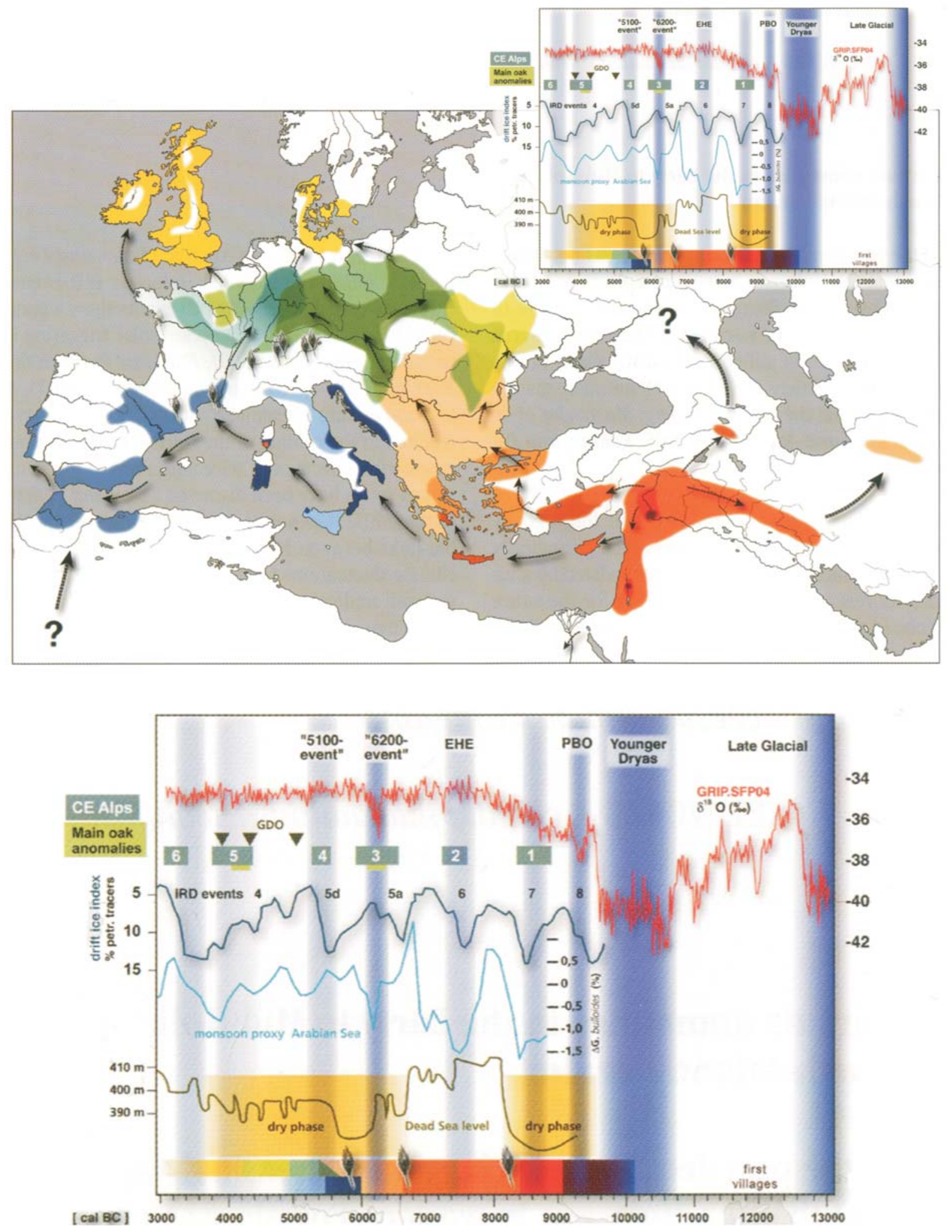

Fig. 9. Culture history informed interpretative chronozone model of the spread of farming across western Eurasia (telescoped time slice layers, non geo referenced). YD - Young Dryas; PBO - pre-Boreal oscillation; EHE - early Holocene event; 6.2-E - 6.2 event; 5.1-E - 5.1 event; LIA - Little Ice Age; CE - cold events; GDO - germination/dying-off events (after Gronenborn, 2009: 98, Fig. 1). Detail is shown in the lower section.

be dated to sometime around $6.0 \mathrm{ka}$ calBP which corresponds to the onset of the RCC (Weninger et al., 2009). Measurements of non-sea salt (nss) $\left[\mathrm{K}^{+}\right]$from GISP2 ice-core let Weninger et al. (2009) to single out cold peaks at about 6162,
5971 and 5746 calBP followed by short warmer period between 5200 and 5150 calBP. The RCC finishes abruptly at 4992 calBP (Fig. 8). Evidence of poorer settlement pattern in this period for a long time was considered to be the result of 


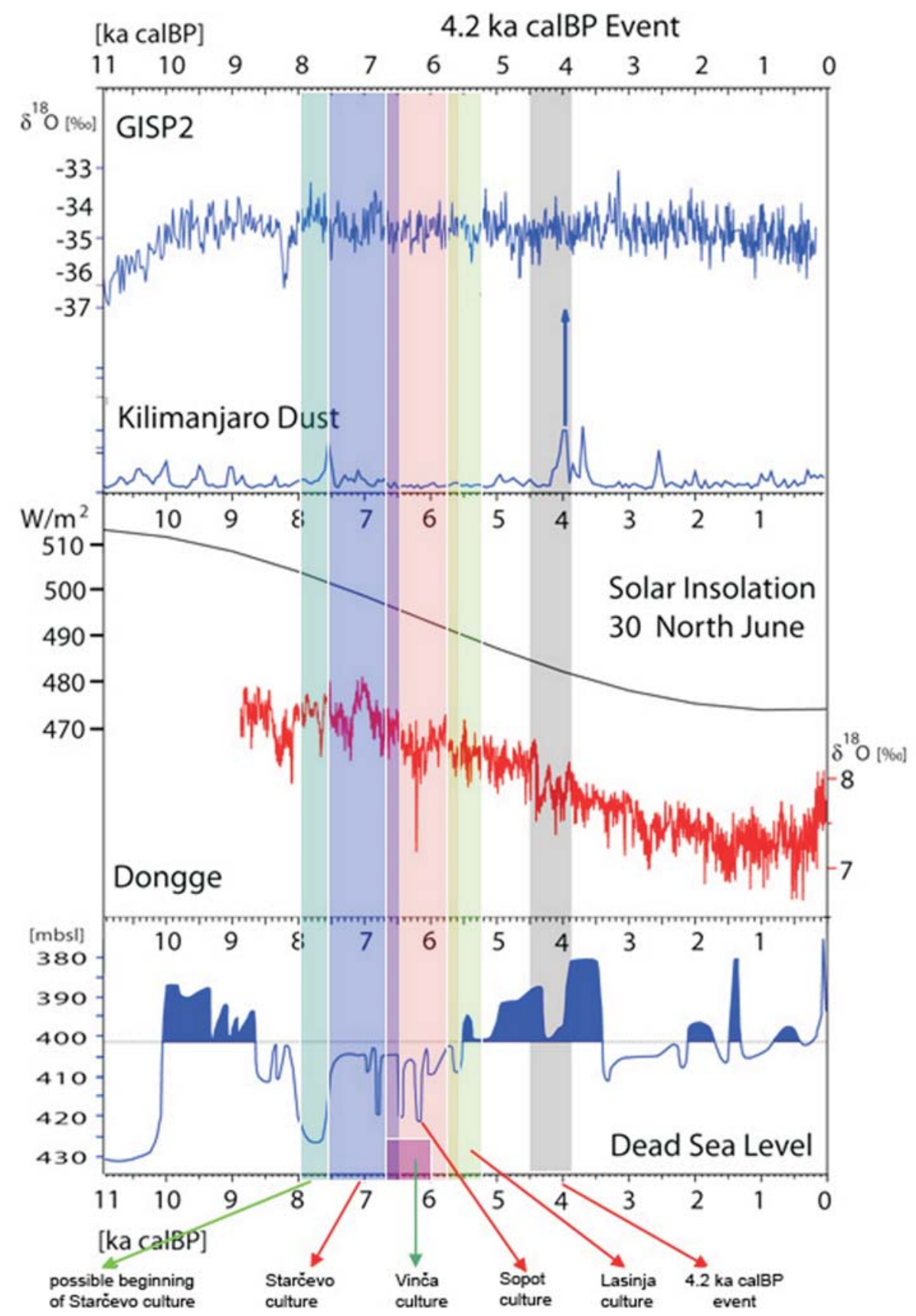

Fig. 10. Climate proxies combined with Neolithic Starčevo and Sopot cultures and Eneolithic Lasinja culture in northern Croatia (modified after Weninger, 2014).

insufficient archaeological research but the new research in Thessaly showed that this lack of settlements during the end of Neolithic/Eneolithic can be linked to abrupt and major move away from tell settlements in favour of a distinct shift towards small upland sites. In recent times, it is also considered that populations shifted from Neolithic agrarian to Copper Age pastoralist economy. At the beginning of the Early Bronze Age, there was a switch back to agriculture (Weninger et al., 2009).

Further analysis of material culture and ${ }^{14} \mathrm{C}$ dates showed that, for example, the tell Dipsis (Ezero) in Thrace was abandoned between 6200 and 5200 calBP, which corresponds to the transition from Karanovo VI to Karanovo VII in cultural terms; the ${ }^{14} \mathrm{C}$ dates show the existence of a major cultural hiatus. This hiatus, between the end of Neolithic and the beginning of the Bronze Age in most of the Greece, lasted about 800 years or longer. The gap is also present in Bulgarian ${ }^{14} \mathrm{C}$ sequence between 6100 and 5200 calBP. Here, as in Greece, the switch from an agrarian (tell-based) economy to pastoralism (with small settlements in upland locations) appears as well as the tell abandonment, for example Yagodna in Western Bulgaria. Yagodna was finally abandoned in the second half of the $6^{\text {th }}$ millennium calBP because the climate became even too extreme to support less sensitive pastoralist economy. Hiatus is also visible in the succession of cultures in this region because the early Bronze Age Ezero culture ap- 
pears in Thrace without any links to any local antecedents (Weninger et al., 2009).

In Romania new research and new ${ }^{14} \mathrm{C}$ dates showed that the end of Eneolithic in southeast Europe can be expected around 6250 calBP. Site of Petriele was destroyed by major burning dated to $6200 \pm 50$ calBP; this date was confirmed by dates from Căscioarele site. Lower Danube and its tributaries were densely populated before 6200 calBP, after which new settlements appeared on the left bank of Danube and in the Dobrogea. Unfortunately, in Romania (as in Greece and Bulgaria) further work is needed to establish sequences and economy of cultures for the 6000-5200 calBP RCC interval (Weninger et al., 2009).

In Tisza River region (Hungary) the life span of tells fall between 5110 and 4450 calBC. The earliest date is from tell Öcsöd-Kováshalom (5110-4830 calBC), situated in the lower flow of Körös River and the latest date is from tell Berettyóújfalu-Herpály (4730-4450 calBC), situated in the eastern part of this region. These radiocarbon dates directly link the end of life at tell sites with the beginning of Eneolithic in Pannonian plain (4500/4450 calBC) (Hertelendi et al., 1998).

\section{CLIMATE PROXIES AS A FRAME FOR ABSOLUTE DATING}

The overview of global climate changes during the beginning of Holocene gave us an insight of how certain periods of significant oscillation in temperature, precipitation and circulation of cold air masses can be linked to partial social change in specific regions. It is clear that the beginning of the Neolithisation of northern Balkan and part of Carpathian basin can't be expected before 6200-6000 calBC (Budja, 2007 ) because the antecedent period was extreme on global scale and the climate conditions in Europe were very unfavourable (dry and cold in the north and south zones, extremely moist in the central zone). Large quantities of precipitation made certain parts of Europe impossible to cross (Budja, 2007; Bánffy and Sümegi, 2012), while in the eastern Mediterranean the severe draft is observed (Budja, 2007; Weninger et al., 2009). Northern Africa was changed by the abrupt arrival of monsoons at that time and desert was replaced by savannah-like environments and quickly inhabited (Kuper and Kröpelin, 2006).

Radiocarbon dates for the beginning of Starčevo culture fit well here: the earliest dates from the sites Sopot and Galovo appear slightly after the end of $8.2 \mathrm{ka}$ calBP event (around 6000 calBC). As the 8.2 calBP event lasted about 160 years (Thomas et al., 2007; Weninger et al., 2009), the beginning of the earliest phase of this culture can be placed at this time. Somewhat earlier date can be expected for the beginning of this culture, but certainly not earlier than 6200 calBC.

Climate proxies show somewhat stronger change during the $7.1 \mathrm{ka}$ calBP event, i.e. between 5700 and 5100 calBC. This change is manifested by decrease of temperature and precipitation in Europe, while less dry conditions in the Middle East prevail. Retrating monsoons caused new desiccation of Sahara at 5300 calBC. During the period between 5300 and 4200 calBC (6250/6200-5200 calBP) in Greece, Bul- garia and Romania tell settlements were abandoned and new smaller upland settlements appeared. The economy also changed from agriculture to pastoralism. The gaps (hiatus) of about 800 to 1000 years appear at that time between old Eneolithic and new early Bronze Age cultures which in general have no connection to their antecedents. Tell abandonment is noted in the eastern part of Pannonian plain after 4450 calBC as well (Hertelendi et al., 1998).

This is the period which corresponds to the end of Starčevo and the beginning of Sopot culture according to radiocarbon dates. Around 5200 calBC climate proxies show the lowest temperature in $7.1 \mathrm{ka}$ calBP event. This can represent the lower date for the end of Starčevo culture but there is not enough radiocarbon data to confirm that. The beginning of Sopot culture should be placed around 5300 calBC (or just after); the greater change in global climate proxies can be observed at that time. After 5300 calBC in southern Balkan and Black Sea region tells were abruptly abandoned and the significant change in social and economic structure of the population appear. In these regions the next new change can be dated only after 4200 calBC.

The last observed 6.0 ka calBP event (4400-3200 calBC) shows very long unstable period in which the most unfavourable are 4600 and 4200 calBC. Sopot culture shows its most intensive existence between 5050 and 4300 calBC, period of dramatic change in eastern regions of Europe. Finally, the change in Sopot culture came late: between 4300 and 4200 calBC the decrease of radiocarbon dates can be observed and after 4200 calBC, while in the wider region Eneolithic is present for a few hundred years, Sopot culture slowly adapts to this new situation before it gives way to Lasinja and other Eneolithic cultures in Slavonia region (southern outskirts of Carpathian basin). Finally, the $4.2 \mathrm{ka}$ calBP marks the full beginning of the Bronze Age in Slavonia region.

\section{CONCLUSION}

Climate change, although not the principal and only cause, had an impact on the social change during the Neolithic and beginning of Eneolithic in southeast and central Europe. Three cold intervals had an impact on the formation, development and final transformation of Neolithic populations in these regions. Comparison of radiocarbon dates with these cold intervals (8.2 ka, 7.1 ka and 6.0 ka cal BP) facilitates, to a certain point, better understanding of specific phases of Neolithic Starčevo and Sopot cultures in northern Croatian territory (southern outskirts of Carpathian basin). The beginning of Starčevo culture can be linked to the end of 8.2 ka cal BP interval while its final phase can be linked to the end of $7.1 \mathrm{ka}$ cal BP interval. The beginning of Sopot culture can be placed somewhat earlier but still during the $7.1 \mathrm{ka}$ cal BP interval. Duration of Sopot culture coincided with the period of tell abandonment in southeast Europe and the Black Sea region and towards its end the decrease of available radiocarbon dates is noted, possibly signifying decrease of life in the region but it is not clear to what extent the life of the known settlements was abandoned. The eponym Sopot site was abandoned around $4200 \mathrm{BC}$ or somewhat later and life there was never renewed. 
It is clear that the beginning of the late Neolithic Sopot culture in southern outskirts of Carpathian basin, i.e. north Croatian territory or Slavonia region, coincides with the major changes in Greece, Romania and Bulgaria where the abrupt abandonment of settlements and great cultural changes happened. It is also clear that the end of Neolithic life in Slavonia region coincides with renewal of life on Balkans and in the Black Sea region. That also marks the beginning of Eneolithic way of life which ends in the second half of the $3^{\text {rd }}$ millennium $\mathrm{BC}$, giving way to the beginning of the Bronze Age just around the time of $4.2 \mathrm{ka}$ calBP event.

There is a possibility that southern outskirts of Carpathian basin, having specific geographic and geological conditions, was able to sustain Neolithic way of life somewhat longer than the surrounding region without any hiatus detected but more interdisciplinary data is needed to confirm this theory.

Lastly, no serious analysis of archaeological remains in the light of climate changes can be done without extensive interdisciplinary research. We consider this paper to be the first step towards this new research.

\section{REFERENCES}

Alley R.B., Mayewski P.A., Sowers T., Stuiver M., Taylor K.C., Clark P.U. 1997. Holocene climatic instability: A prominent, widespread event 8200 yr ago. Geology 25 (6), 483-486.

Alley R.B., Ágústsdóttir A.M. 2005. The 8k event: cause and consequences of a major Holocene abrupt climate change. Quaternary Science Reviews 24 (10-11), 1123-1149.

Bačani A., Šparica, M., Velić J. 1999. Quaternary as the Hydrogeological System of Eastern Slavonia. Geologia Croatica 52/2, 141-152.

Bailey D.W. 2006. Holocene changes in the level of the Black Sea: consequences at a human scale. In: Yanko-Hombach V., Gilbert A. S., Panin N., Dolukhanov P. M. (eds.), The Black Sea flood question: changes in coastline, climate, and human settlement, 515-536. Dordrecht: Springer.

Balen J. 2008. Absolute dates acquired from rescue excavations in Slavonija as a contribution to middle Eneolithic chronology. Vjesnik Arheološkog muzeja u Zagrebu 3.s. XLI, 17-35 (in Croatian with English summary).

Balen J., Bilić T., Bunčić M., Drnić I., Solter A. 2009. Results of rescue excavations on the site of Ivandvor-Gaj forest. Vjesnik Arheološkog muzeja u Zagrebu XLII, 23-72 (in Croatian with English summary).

Bánffy E. 2004. The 6th Millennium BC boundary in western Transdanubia and its role in the Central European Neolithic transition (The Szentgyörgyvölgy-Pityerdomb Settlement). Varia Archaeologica Hungarica XV. Budapest.

Bánffy E., Sümegi P. 2012. The Early Neolithic Agro-Ecological Barrier in the Carpathian Basin: A Zone for Interaction. In: Andreiter P., Bánffy E., Bartosiewicz L., Meid W., MetznerNebelsick C. (eds.), Archaeological, Cultural and Linguistic Heritage. Festschrift for Erzsébet Jerem in Honour of her 70th Birthday, 57-69. Archaeolingua Main Series 25, Budapest.

Barna J.P. Pásztor E. 2011. Different ways of using space: traces of domestic and ritual activities at a Late Neolithic settlement at Sormás-Török-földek. Documenta Praehistorica XXXVIII, 185-206.

Berger J.-F., Guilaine J. 2009. The 8200 calBP abrupt environmental change and the Neolithic transition: A Mediterranean perspective. Quaternaty International 200, 31-49.

Biagi P., Spataro M. 2005. New observations on the radiocarbon chronology of the Starčevo-Criş and Körös cultures. In: Nikolova L., Higgins J. (eds.), Prehistoric Archaeology and Anthropological Theory and Education. Reports of Prehistoric Research Projects 6-7, 35-40.

Biagi P., Shennan S., Spataro M. 2005. Rapid rivers and slow seas? - New data for the radiocarbon chronology of the Balkan peninsula. In: Nikolova L., Higgins J. (eds.), Prehistoric Archaeology and Anthropological Theory and Education. Reports of Prehistoric Research Projects 6-7, 41-52.

Bianchi G.G., McCave I.N. 1999. Holocene periodicity in North Atlantic climate and deep-ocean flow south of Iceland. Nature 397, 515-517.

Bocquet-Appel J.-P., Naji S., Vander Linden M., Kozlowski J.K., 2009. Detection of diffusion and contact zones of early farming in Europe from the space-time distribution of $14 \mathrm{C}$ dates. Journal of Archaeological Science 36, 807-820.

Bond G., Showers W., Cheseby M., Lotti R., Almasi P., deMenocal, P., Priore P., Cullen H., Hajdas I., Bonani G. 1997. A Pervasive Millennial-Scale Cycle in North Atlantic Holocene and Glacial Climates. Science 278 (Nov), 1257-1266.

Bond G., Kromer B., Beer J., Muscheler R., Evans M.N., Showers W., Hoffmann S., Lotti-Bond R., Hajdas I., Bonani G. 2001. Persistent Solar Influence on North Atlantic Climate During the Holocene. Science 294, 2130-2136.

Borić D. 2009. Absolute Dating of Metallurgical Innovations in the Vinča Culture of the Balkans. In: Kienlin T.K., Roberts B.W. (eds.), Metals and Societies. Studies in honour of Barbara S. Ottaway, Universitätsforschungen zur Prähistorischen Archäologie Bd. 169, 191-245. Bonn.

Bout-Roumazeilles V., Comboureu Nebout N., Peyron O., Cortijo E., Landais A., Masson-Delmotte V. 2007. Connection between South Mediterranean climate and North African atmospheric circulation during the last 50,000 yr BP North Atlantic cold events. Quaternary Science Reviews 26, 3197-3215.

Budja M. 2007. The 8200 calBP 'climate event' and the process of neolithisation in south-eastern Europe. Documenta Praehistorica XXXIV, 191-201.

Budja M. 2013. Potters and Pots in the Mesolithic-Neolithic Transformation in Southeastern Europe. In: Anders A., Kulcsár G. (eds.), Moments in time, Papers Presented to Pál Raczky on His $60^{\text {th }}$ Birthday, 61-83. Budapest.

Burić M. 2015. Problems of the Late Neolithic Absolute Chronology in Eastern Croatia. Archäologie in Eurasien 31, 143-156.

Burić M., Težak-Gregl T. 2009. Geo-pedological and climatic impact on the distribution and organization of Neolithic settlements in Eastern Croatia (Western Syrmia). Documenta Praehistorica XXXVI, 337-346.

Cacho I., Grimalt J.O., Canals M., Sbaffi L., Shackleton N.J., Schoenfeld J., Zahn R. 2001. Variability of the western Mediterranean Sea surface temperature during the last 25,000 years and its connection with the Northern Hemisphere climatic changes. Paleoceanography 16(1), 40-52.

Carozza J.-M., Micu C., Mihail F., Carozza L. 2012. Landscape changes and archaeological settlements in the lower Danube valley and delta from early Neolithic to Chalcolithic time: A review. Quaternary International 261, 21-31.

Clare L., Rohling E.J., Weninger B., Hilpert J. 2008. Warfare in Late Neolithic/Early Chalcolithic Pisidia, southwestern Turkey. Climate induced social unrest in the late 7 th millennium cal. BC. Documenta Praehistorica XXXV, 65-92.

Clare L., Weninger B., 2010. Social and biophysical vulnerability of prehistoric societies to Rapid Climate Change. Documenta Praehistorica XXXVII, 283-292.

Čataj L., Janeš A. 2013. Golinci-Selište. Prehistoric and Medieval settlement. In:Višnjić, J. (ed.), New archaeological insight into lower Podravina. Rescue Archaeology Research of the Slobo- 
dnica - Donji Miholjac Natural Gas Trunk Pipeline, 167-225. Zagreb (in Croatian and English).

Čufar K., Grabner M., Morgós A., Martínez del Castillo E., Merela M., de Luis M. 2014. Common climatic signals affecting oak tree-ring growth in SE Central Europe. Trees 28, 1267-1277.

Čufar K., de Luis M., Zupančič M., Eckstein D. 2008. A 548-year tree-ring chronology of oak (Quercus spp.) for southeast Slovenia and its significance as a dating tool and climate archive. Tree-Ring Research 64(1), 3-15.

Dimitrijević S. 1968. Die Sopot-Lengyel Kultur. Monographiae Archaeologicae 1. Zagreb (in Croatian with German summary).

Dimitrijević S. 1969. Die Starčevo-Kultur im slawonisch-syrmischen Raum und das Problem des übergangs vom älteren zum mittleren Neolithikum im serbischen und kroatischen Donaugebeit, Simpozij Neolit i eneolit u Slavoniji, Vukovar, 4.-5. lipnja 1966. Actes 5, Vukovar (in Croatian with German summary).

Dimitrijević S. 1971. Das Neolithikum in Syrmien, Slawonien und Nordwestkroatien - Einführung in den Stand der Forschung. Archaeologia Iugoslavica X/1969, 39-76.

Dimitrijević S. 1979. North zone (Sjeverna zona). In: Benac A. (ed.), Praistorija jugoslavenskih zemalja II - Neolitsko doba, Sarajevo, 229-360 (in Croatian lang.).

Feurdean A., Klotz S., Misbrugger V., Wohlfarth B. 2008. Pollenbased quantitative reconstructions of Holocene climat variability in NW Romania. Palaeoclimatology, Palaeogeography, Palaeoecology 260, 494-504.

Fletcher W.J., Sánchez Goñi M.F. 2008. Orbital- and sub-orbital climate impacts on vegetation of the western Mediterreanean basin over the last 48,000 yr. Quaternary Research 70, 451- 464.

Galović L. 2005. Geochemical and mineralogical characteristic of the Plistocene paleosols in loess profiles in Eastern Slavonia and Baranja. Dissertation (in Croatian lang.).

Galović L., Frechen M., Halamić J., Durn G., Romić M. 2009. Loess chronostratigraphy in Eastern Croatia - A luminescence dating approach. Quaternary International 198, 85-97.

Grootes P.M., Stuiver M., White J.W.C., Johnsen S., Jouzel J. 1993. Comparison of Oxygen Isotope Records from the GISP2 and GRIP Greenland Ice Core. Nature 366, 552-554.

Gronenborn D. 2009. Climate fluctuations and trajectories to complexity in the Neolithic: towards a theory. Documenta Praehistorica XXXVI, 97-110.

Gronenborn D., Sirocko F. 2009. Frühholozänes Wärmeoptimum und neolithische Expansion. In: Sirocko, F. (ed.), Wetter, Klima, Menschheitsentwicklung - Von der Eisenzeit bis ins 21. Jahrhundert, 108-112. Mainz.

Gulýas S., Sümegi P. 2011. Farming and/or foraging? New environmental data to the life and economic transformation of Late Neolithic tell communities (Tisza Culture) in SE Hungary. Journal of Archaeological Science 38, 3323-3339.

Haase D., Fink J., Hasse G., Ruske R., Pécsi M., Richter H., Altermann M., Jäger K.-D. 2007. Loess in Europe - its spatial distribution based on a European Loess Map, scale 1:2,500,000. Quaternary Science Reviews 26, 1301-1312.

Hertelendi E., Kalicz N., Raczky P., Horváth F., Veres M., Svingor E., Futó I., Bartosiewicz L. 1995. Re-evaluation of the Neolithic in Eastern Hungary based on calibrated radiocarbon dates. In Cook G.T., Harkness D.D., Miller B.F., Scott E.M. (eds.), Proceedings of the $15^{\text {th }}$ International ${ }^{14} \mathrm{C}$ Conference, Radiocarbon Vol. 37 - No. 2, 239-244.

Hertelendi E., Svingor É., Raczky P., Horváth F., Futó I., Bartosiewicz L. 1998. Duration of tell settlements at four prehistoric sites in Hungary. In: Mook W.G., van der Pilcht J. (eds.), Proceedings of the $16^{\text {th }}$ International ${ }^{14} \mathrm{C}$ Conference, Radiocarbon Vol. 40 - No. 2, 659-665.

Hu F.S., Slawinski D., Wrigt Jr H.E., Ito E., Johnson R.G., Kelts K.R., McEwan R.F., Boedigheimer A. 1999. Abrupt changes in North American climate during early Holocene times. Nature 400(29), 437-440.

Kalicz N., Kreiter E., Tokai Z.M. 2007. Die Rolle der Sopot-Kultur in der Entstehung der Lengyel-Kultur auf Grund der neuen Ausgrabungen in Südwestungarn. In: Kozłowski J.K., Raczky P. (eds.), The Lengyel, Polgár and related cultures in the Middle/Late Neolithic in Central Europe, 29-47. Kraków.

Kotova N. 2009. The Neolithization of Northern Black Sea area in the context of climate changes. Documenta Praehistorica XXXVI, 159-174.

Kotova, N., Makhortykh, S. 2010. Human adaptation to past climate changes in the northern Pontic steppe. Quaternary International 220, 88-94.

Krajcar Bronić I., Minichreiter K. 2007. ${ }^{14} \mathrm{C}$ dating of early Neolithic settlement Galovo near Slavonski Brod in Northern Croatia. Nuclear Instruments and Methods in Physics Research 580, 714-716.

Krajcar Bronić I. 2011. ${ }^{14} \mathrm{C}$ Method of age determination and the example of dating two Neolithic settlements in Croatia. In: Dizdar M. (ed.) Panonski prapovijesni osviti - Zbornik radova posvećen Korneliji Minichreiter uz 65. obljetnicu života, 175189. Zagreb (in Croatian lang. with English summary).

Krznarić Škrivanko M. 2007. Site: Sopot. Hrvatski arheološki godišnjak 3/2006, 45-47 (in Croatian lang. with English summary).

Krznarić Škrivanko M. 2011. Radiocarbon dates of samples from Sopot. In: Dizdar, M. (ed.), Panonski prapovijesni osviti Zbornik radova posvećen Korneliji Minichreiter uz 65. obljetnicu života, 209-225. Zagreb (in Croatian lang. with English summary).

Kuper R., Kröpelin S. 2006. Climate-Controlled Holocene Ocupation in the Sahara: Motor of Africa's Evolution. Science 313 (Aug), 803-807.

Lazarovici C.-M. 2006. Absolute chronology of the Late Vinča culture in Romania and its role in the development of the Early Copper Age. In: Tasić N., Grozdanov C. (eds.), Homage to Milutin Garašanin, SASA Special Editions, 277-293. Beograd.

Lazarovici C.-M. Lazarovici G. 2007. Arhitectura neoliticului şi epocii cuprului din România, Vol. II - Epoca cuprului. Iaşi.

Lemmen C., Gronenborn D., Wirtz K.W. 2011. A simulation of the Neolithic transition in Western Eurasia. Journal of Archaeological Science 38, 3459-3470.

Link T. 2006. Das Ende der neolithischen Tellsiedlungen. Ein kulturgeschichtliches Phänomen des 5. Jahrtausends v. Chr. im Karpatenbecken. Universitätsforschungen zur Prähistorischen Archäologie 134. Bonn.

Link T. 2009. Das Ende der spätneolithischen Tellsiedlungen im Karpatenbecken - der Beginn einer mobileren Lebensweise? In: Varia neolithica V, Mobilität, Migration und Kommunikation in Europa während des Neolithikums und der Bronzezeit, Beiträge der Sitzungen der Arbeitsgemeinschaften Neolithikum und Bronzezeit während der Jahrestagung des Westund Süddeutschen Verbandes für Altertumsforschunge V. in Xanten, 6. - 8. Juni 2006. Beiträge zur Ur- und Frühgeschichte Mitteleuropas 53, 95-101.

Magny M., Bégeot C., Guiot J., Peyron O. 2003. Contrasting patterns of hydrological changes in Europe in response to Holocene climate cooling phases. Quaternary Science Reviews 22, $1589-1596$.

Marijan B. 2001. Archaeological rescue excavations at the site along the southern carriageway of the motorway Zagreb - Lipovac, section Velika Kopanica - Županja, subsection Babina Greda-Županja. Obavijesti Hrvatskog arheološkog društva XXXIII/2, 35-45 (in Croatian lang. with English summary).

Marijan B. 2006. The Neolithic site Dubovo-Košno near Županja. In Tomaž A. (ed.), Od sopota do Lengyela, Založba Annales, 
43-51. Koper (in Croatian lang. with English summary).

Marković Z. 1985. Zur Problem des fruhen Aeneolithikums in Nordwestkroatien. Vjesnik Arheološkog muzeja u Zagrebu 3. ser. 18, 1-34, T. 1-11 (in Croatian lang. with German summary).

Marković Z. 1994. Nordkroatien vom Neolithikum bis zur Anfang der Bronzezeit - Das Problem der Kontiuität der Bevölkerung und Kulturen im Nordkroatien vom Frühneolithikum bis zur Anfang der Bronzezeit. Muzej grada Koprivnice, Koprivnica (in Croatian lang. with German summary).

Marković Z. 2012. Neuere Betrachtunen über bestimmte Aspekte der Sopot-kultur in Nordkroatien. Prilozi Instituta za arheologiju u Zagrebu 29, 57-69.

Mayewski P.A., Rohling E.E., Stager J.C., Karlén W., Maasch K.A., Meeker L.D., Meyerson E.A., Gasse F., van Kreveld S., Holmgren K., Lee-Thorp J., Rosqvist G., Rack, F., Staubwasser M., Schneider R.R., Steig E.J. 2004. Holocene climate variability. Quaternary Research 62(3), 243-255.

Mayewski P., Meeker L.D., Twickler M.S., Whitlow S., Yang Q., Lyons W.B., Prentice M. 1997. Major features and forcing of high latitude northern hemisphere circulation using a 110,000-year-long glaciochemical series. Journal of Geophysical Research (C12), 26345-26366.

Meeker L.D., Mayewski P.A. 2002. A 1400 year long record of atmospheric circulation over the North Atlantic and Asia. The Holocene 12(3), 257-266.

Mihaljević M. 2013. Sopot culture in western Slavonia with the special review of Slavča-Nova Gradiška site (Sopotska kultura u zapadnoj Slavoniji s posebnim osvrtom na nalazište SlavčaNova Gradiška). Dissertation (in Croatian lang.).

Minichreiter K. 1992. The Starčevo Culture in Northern Croatia-A contribution to research into early Neolithic settlements. Dissertationes et monographiae 1, Zagreb (in Croatian lang. with English summary).

Minichreiter K. 2001. The architecture of Early and Middle Neolithic settlements of the Starčevo culture in Northern Croatia. Documenta Praehistorica XXVIII, 199-214.

Minichreiter K. 2007. Slavonski Brod, Galovo - Ten years of archaeological research. Monografije Instituta za arheologiju vol. I. Zagreb (in Croatian with English summary).

Minichreiter K., Krajcar Bronić I. 2006. New Radiocarbon Dates for the Early Starčevo Culture in Croatia/Novi radiokarbonski datumi rane starčevačke kulture u Hrvatskoj. Prilozi Instituta za arheologiju u Zagrebu 23, 5-16.

Obelić B., Krajcar Bronić I., Horvatinčić N. 2002. Rudjer Bošković Institute radiocarbon measurements XV. Radiocarbon 44 (2), 601-630.

Obelić B., Krznarić Škrivanko M., Marijan B., Krajcar Bronić I., 2004. Radiocarbon dating of Sopot culture sites (Late Neolithic) in Eastern Croatia. Radiocarbon 46 (1), 245-258.

Obelić B., Krajcar Bronić I., Horvatinčić N., Barešić J., Rajtarić A. 2011. Rudjer Bošković Institute radiocarbon measurements XVI. Radiocarbon 53 (2), 395-417.

Ogutsov M.G., Kocharov G.E., Lindholm M., Eronen M., Nagovitsyn Y.A. 2001. Solar activity and regional climate. Radiocarbon 43 (2A), 439-447.

Pearson C.L., Ważny T., Kuniholm P.I., Botić K., Durman A., Seufe K. 2014. Potential for a new multimillennial tree-ring chronology from subfossil Balkan river oaks. Radiocarbon 56 (4), S51-S59.

Perry Ch.A., Hsu K. 2000. Geophysical, archaeological, and historical evidence support a solar-output model for climate change. Proceedings of the National Academy of Sciences vol. 97 - no. 23 (Nov), 12433-12438.

Rohling E.J., Casford J., Abu-Zied R., Cooke S., Mercone D., Thomson J., Croudace I., Jorissen F.J., Brinkhuis H., Kallmeyer J., Wefer G. 2002. Rapid Holocene climate changes in the eastern
Mediterranean. In: F. Hassan (ed.), Droughts, Food and Culture: Ecological Change and Food Security in Africa's Later Prehistory. Kluwer Academic/Plenum Publishers, New York.

Sraka M. 2012.${ }^{14} \mathrm{C}$ calendar chronologies and cultural sequences in $5^{\text {th }}$ millennium $\mathrm{BC}$ in Slovenia and neighbouring regions. Documenta Praehistorica XXXIX, 385-412.

Sümegi P., Kertész R., Hertelendi E. 2002. Environmental change and human adaptation in the Carpathian basin at the Late Glacial/Postglacial transition. In: Jerem E., Biró K.T. (eds.), Archaeometry 98, Proceedings of the $31^{\text {st }}$ International Symposium on Archaeometry, 171-177. BAR I.s. 1043(1). London.

Šimić J. 2000. Research of the Neolithic site Hermanov vinograd in Osijek. Histria Antiqua 6, Pula, 223-230 (in Croatian lang. with English summary).

Šimić J. 2006. Sites of the Sopot culture in the Osijek area. In: Tomaž A. (ed.), Od sopota do Lengyela, 39-42. Koper, (in Croatian lang. with English summary).

Thomas E.R., Wolff E.W., Mulvaney R., Steffensen J.P., Johansen S.J., Arrowsmith C., White J.W.C., Vaughn B., Popp T. 2007. The $8.2 \mathrm{ka}$ event from Greenland ice cores. Quaternary Science Reviews 26(1-2), 70-81.

Welc F., Marks L. 2014. Climate change at the end of the Old Kingdom in Egypt around 4200 BP: New geoarchaeological evidence. Quaternary International 324, 124-133.

Weninger B., Alram-Stern E., Bauer E., Clare L., Danzeglocke U., Jöris O., Kubatzki C., Rollefson G., Todorova H., van Andel T. 2006. Climate forcing due to the $8200 \mathrm{cal} \mathrm{yr} \mathrm{BP} \mathrm{event} \mathrm{observed}$ at Early Neolithic sites in the eastern Mediterranean. Quaternary Research 66, 401-420.

Weninger B., Alram-Stern E., Bauer E., Clare L., Danzeglocke U., Jöris O., Kubatzki C., Rollefson G., Todorova H., van Andel T. 2007. Abrupt Climate Forcing observed at Early Neolithic sites in South-East Europe and the Near East, The Struma/ Strymon River Valley in Prehistory, Proceedings of the International Symposium Strymon Praehistoricus, Kjustendil-Blagoevgrad (Bulgaria) and Serres-Amphipolis (Greece) 27.0901.10.2004. In: Todorova H., Stefanovich M., Ivanov G. (eds.), The Steps of James Harvey Gaul, vol. 2, 19-40. Sofia.

Weninger B., Schulting R., Bradtmöller M., Clare L., Collard M., Edinborough K., Hilpert J., Jöris O., Niekus M., Rohling E.J., Wagner B. 2008. The catastrophic final flooding of Doggerland by the Storegga Slide tsunami. Documenta Praehistorica, XXXV, 1-24.

Weninger B., Clare L., Rohling E.J., Bar-Yosef O., Böhner U., Budja M., Bundschuh M., Feurdean A., Gebel H.-G., Jöris O., Linstädter J., Mayewski P., Mühlenbruch T., Reingruber A., Rollefson G., Schyle D., Thissen L., Todorova H., Zielhofer C. 2009. The Impact of Rapid Climate Change on prehistoric societies during the Holocene in the Eastern Mediterranean. Documenta Praehistorica XXXVI, 7-59.

Weninger B. 2014. Archaeological and Palaeoclimatological Data to Evaluate the Potential Impact of the $4.2 \mathrm{ka}$ cal. BP event in the Eastern Mediterranean, The Early/Middle Bronze Age Transition in the Ancient Near East: Chronology, ${ }^{14} \mathrm{C}$ and Climate Change, Oriental Institute Annual Symposium 2013/ 2014 (7th-8th March), Chicago, in press (abstract available at https://oi.uchicago.edu/research/symposia/earlymiddlebronze-age-transition-ancient-near-east-chronology-c14and-climate 9.2.2014.)

Weninger B., Clare L., Gerritsen F., Horjes B., Krauß R., Linstädter J., Özbal R., Rohling E.J. 2014. Neolithisation of the Aegean and Southeast Europe during the 6600-6000 calBC period of Rapid Climate Change. Documenta Praehistorica XLI, 1-31.

Zaninović K. (ed.) 2008. Climate atlas of Croatia. Državni hidrometeorološki zavod / Meteorological and Hydrological Service of Croatia, Zagreb (in Croatian and English). 